\title{
Laparoscopy-Assisted Versus 0pen Gastrectomy for Gastric Cancer: A Comprehensive Systematic Review and Meta-Analysis Based on Randomized Controlled Trials
}

\author{
Rawan Khalid Abdulgadir Salih* \\ Faculty of medicine, Alneelain University, Khartoum, Sudan
}

Submission: September 19, 2019; Published: October 14, 2019

"Correspondence Author: Rawan Khalid Abdulgadir Salih, Faculty of medicine, Alneelain University, Khartoum, Sudan

\begin{abstract}
Background: This meta-analysis was conducted to evaluate the safety and effectiveness of laparoscopy-assisted gastrectomy compared to conventional surgery for gastric cancer. Previous meta-analyses lacked statistical power to reach a definitive conclusion.

Methods: Randomized controlled trials (RCTs) comparing LAG with OG for gastric cancer published until May 2019 were retrieved using Mendeley, PubMed, EMBASE, the Cochrane Library and Google Scholar databases. The Cochrane Risk of Bias tool was used to assess the methodological quality of the included RCTs. Operative outcomes, post-operative outcomes and oncological outcomes were analyzed using random effects model. Statistical analysis was performed using Review Manager 5.3. The quality of evidence was assessed using the Grading of Recommendation Assessment, Development and Evaluation guidelines (GRADE) guidelines.

Results: Seventeen trials totaling 5198 participants were included in this meta-analysis. In comparison with open surgery, laparoscopy-assisted gastrectomy showed less intra-operative blood loss (MD -73.55, 95\% CI -98.17 to $-48.93, \mathrm{P}<0.00001$ ), shorter time to first ambulation (MD -0.49 , 95\% CI -0.89 to $-0.09, \mathrm{P}<0.02$ ), flatus (MD $-1.14,95 \% \mathrm{CI}-1.68$ to $-0.60, \mathrm{P}<0.0001$ ) and oral intake (MD $-0.59,95 \% \mathrm{CI}-1.03$ to $-0.14, \mathrm{P}<0.01$ ), shorter hospitalization (MD -1.15, 95\% CI -1.90 to -0.40 , P < 0.00001), lower overall post-operative morbidity (OR $0.80,95 \%$ CI 0.65 to 0.99 ), $\mathrm{P}=0.04$ ), the operative time was significantly longer for the laparoscopic approach group (MD 67.90, 95\% CI 54.51 to 81.30, $\mathrm{P}<0.00001$ ). No significant difference was found between the LAG and OG regarding mortality rates and incidence of reoperation, which supports the safety of LAG. The number of harvested lymph nodes and tumor recurrence/metastasis did not significantly differ between the two groups, indicating oncological equivalence of both approaches.
\end{abstract}

Conclusion: Although LAG is a technically demanding and time-consuming procedure, it can be used as an acceptable and safe alternative to OG, with better short-term results.

Keywords: Gastric cancer; Laparoscopy-assisted gastrectomy; Open gastrectomy

\section{Introduction}

Gastric cancer is a major health problem worldwide $[1,2]$. It is now the fifth common cancer and the second leading cause of cancer-related mortality in the world, accounting for more the $10 \%$ of the annual cancer deaths globally [3-6]. There is global variation in the incidence of gastric cancers with higher incidence in Southeast Asia specially Korea and Japan and much lower incidence in Africa, Australia and USA. The treatment of gastric cancer depends upon the stage of the disease. One of the commonest staging systems is the American Joint Committee on Cancer (AJCC) gastric cancer staging system - AJCC 7th edition, known as the TNM classification $[7,8]$. In stage I to III, radical surgery in the form of gastrectomy and lymph nodes dissection is the mainstay of the treatment and the aim is cure of the disease. In stage IV, palliative treatment is recommended.

Laparoscopy-assisted gastrectomy for gastric cancer was first introduced in 1991 and reported by Kitano et al in 1994 [9]. Since that time, it gains acceptance due to its advantages over open gastrectomy as a result of minimal invasion. In 1997, a study published by Goh et al showed that laparoscopy-assisted gastrectomy was superior to conventional open surgery because of less pain, faster recovery and better cosmetic outcomes [10]. Laparoscopy-assisted gastrectomy is frequently used 
in Asian countries mainly Korea and Japan, where screening programs resulting in early diagnosis and better prognosis than other countries [11-15]. In spite of its advantages, it remains controversial and still not become an alternative to conventional open gastrectomy because of the complexity of the procedure especially in establishing the continuity of the digestive tract (reconstruction) and extended lymph nodes dissection. Furthermore, the oncological safety (cancer clearance) of laparoscopic-assisted gastrectomy is not yet well-established [16]. Another concern is the post-site recurrence, associated with pneumoperitoneum and visceral manipulation, which have been report by Azagra et al. [17].

The continuing controversy led researchers focus on this area by conducting RCTs and non-RCTs comparing laparoscopyassisted gastrectomy with open gastrectomy [18-31]. But the sample size of these studies is not adequate to define the superiority of LAG over the open technique. Several metaanalyses were conducted in the last decay, some of them include few RCTs, they include data from 734, 390 and 732 patients respectively [32-34]; they may have included a false positive errors and they lacked statistical significance to reach a final conclusions because of the relatively small sample size of these meta-analyses [16]; Other meta-analyses combined both RCTs and non-RCTs, but, Publication bias is likely to be greater for nonRCTs because the quality of evidence is much lower than that of RCTs. Consequently, the results of meta-analyses including non-RCTs should be interpreted with caution [35]. Furthermore, most of the previous meta-analyses did not reported on both early and advanced gastric cancer. Additional RCTs have been published and will strengthen the current evidence. Therefore, it is necessary to carry out a meta-analysis by pooling of the results of all available published RCTs up to date to evaluate the safety and effectiveness of LAG over open gastrectomy in gastric cancer, this will help surgeons in clinical decision making.

\section{Materials and Methods}

The meta-analysis was performed in accordance with the recommendations of the Preferred Reporting Items for Systematic Reviews and Meta-analysis statement (PRISMA) statement [36].

\section{Literature Search Strategy}

A comprehensive systematic literature search using Mendeley, PubMed, EMBASE, the Cochrane Library and Google Scholar databases for studies published until May 2019. Only articles published in English language were included in this meta-analysis. No language restriction was provided. The Following Medical Subject Headings (MeSH) AND free-text terms were used: gastric cancer; gastric carcinoma; stomach cancer; gastric neoplasm's; stomach neoplasm's; laparoscopic-assisted; laparoscopy-assisted; minimally invasive; open gastrectomy; conventional gastrectomy; laprarotomy; Randomized controlled trial. Logistic combinations between these terms were used to maximize sensitivity. The PubMed database was used to search for additional studies using authors' names. Trials were identified also by using related-articles function in the PubMed. The search was extended further by searching the reference lists of all retrieved articles and previous meta-analyses.

\section{Study Selection}

The author screens the primary data from the studies collected in the electronic search. The following eligibility criteria were applied for inclusion of the studies in the metaanalysis:

\section{i. Be a published randomized controlled trial.}

ii. Studies comparing laparoscopy-assisted with open gastrectomy for gastric cancer, regardless of the type of gastrectomy performed (total gastrectomy, distal gastrectomy and proximal gastrectomy) and regardless of the tumor stage ( early or advanced gastric cancer).

iii. Histological proven of adenocarcinoma of the stomach through endoscopic biopsy

iv. Trials reporting at least one of the following outcome measures: operative outcomes (operative time, intraoperative blood loss, and transfused patients), postoperative outcomes( post-operative analgesic consumption, time to first ambulation, time to first flatus, time to first oral intake, length of post-operative hospital stay, overall post-operative morbidity, post-operative surgical and medical complications \{ abdominal abscess, anastomotic leakage, anastomotic stenosis, bleeding, gastroparesis, ileus, intestinal obstruction, pancreatic fistula, pancreatitis, wound infection and pneumonia\}, incidence of reoperation, and mortality), and Oncological outcomes( number of harvested lymph nodes, tumor recurrence and metastasis).

Studies was excluded from this meta-analysis if

a. They were non-RCTs.

b. They were not comparative studies.

c. They reported on gastric surgery for benign gastric diseases or malignant stromal tumors.

d. They reported on robotic surgery, hand-assisted laparoscopic gastrectomy, or gasless laparoscopic surgery.

e. They included on gastrectomy for recurrent gastric cancer.

f. They reported on emergency gastrectomy.

g. They were not published in English language.

h. The outcomes of interests were not reported for the two techniques. If two or more articles were published by the same team in the same institution, then the better quality or the most recent publication was included in the meta-analysis to avoid including the same patients. 


\section{Data Extraction}

Data were extracted using a data extraction forms designed for this study. The following data were extracted from each included study: the first authors' name, year of publication, country, study center, number of participants, number of subject operated on each technique, type of gastrectomy, extent of lymphadenctomy, type of reconstruction, follow-up (months), and patients characteristics including age, sex, BMI, ASA score, co-morbidities, pathological tumor/metastasis stage, tumor size, tumor location, histological type, adjuvant treatment, and the outcomes of interest.

\section{Methodological Quality Assessment}

The quality and risk of bias for each included RCT was evaluated using the Cochrane Risk of Bias tool which is recommended in the Cochrane Collaboration Handbook 5.1.0 [37]. The following domains were assessed: Random sequence generation; allocation concealment; blinding of participants and personnel (performance bias); blinding of the outcome assessment (detection bias); incomplete outcome data (attrition bias); selective reporting; and other bias. The risk of bias in each domain was examined and classified as low, high or unclear.

\section{Quality of Evidence}

We assessed the quality of evidence of the study outcomes using the GRADE assessment tool as provided by the Cochrane Collaboration. The overall quality of evidence was scored as very low, low, moderate and high according to the evaluation of the risk of bias, inconsistency, indirectness, imprecision and other considerations.

\section{Statistical Analysis}

Statistical analysis was performed using Review Manager 5.3 (Nordic Cochrane center, Copenhagen, Denmark). The odd ratios (ORs) and 95\% confidence intervals (CIs) were calculated for dichotomous variables including transfused patients, overall post-operative morbidity, short-term mortality, post-operative surgical and medical complications, incidence of reoperation and tumor recurrence and metastasis. Weighted mean differences (WMDs) with 95\% confidence intervals (CIs) were calculated for continuous variables including operative time, intra-operative blood loss, post-operative analgesic consumption, time to first ambulation, time to first flatus, time to first oral intake, length of post-operative hospital stays, number of harvested lymph nodes.

\section{Results}

\section{Study selection and Characteristics}

The search strategy yielded 1018 articles. 23 additional articles were identified through other sources. After completion of manually removing duplicates, 588 publications remain. These articles were screened for eligibility based on abstracts and full texts if required. Of these studies, 531 were excluded according to the exclusion criteria of this meta-analysis. The full texts of the remaining 57 articles were screened for eligibility. Of them, thirteen articles were not RCTs [26-31], eleven were meta-analyes [32-34,38-55], and two studies compared total laparoscopic gastrectomy to open gastrectomy and were excluded [56,57]. Three studies compared open gastrectomy to robotic surgery and therefore were excluded [58-60]. One study compared open gastrectomy to hand-assisted laparoscopic surgery and thus was excluded [61]. Two studies did not provide any data for the control group and were excluded [62,63]. Eight trials were excluded because they thought to be published in the same institution by the same team $[24,25,64-69]$. Seventeen studies were eventually included in the current meta-analysis [18-23,70-80]. Necessary information was still obtained from the eight excluded studies [24,25,64-69]. A flow diagram of the trial selection process is shown in (Figure 1).

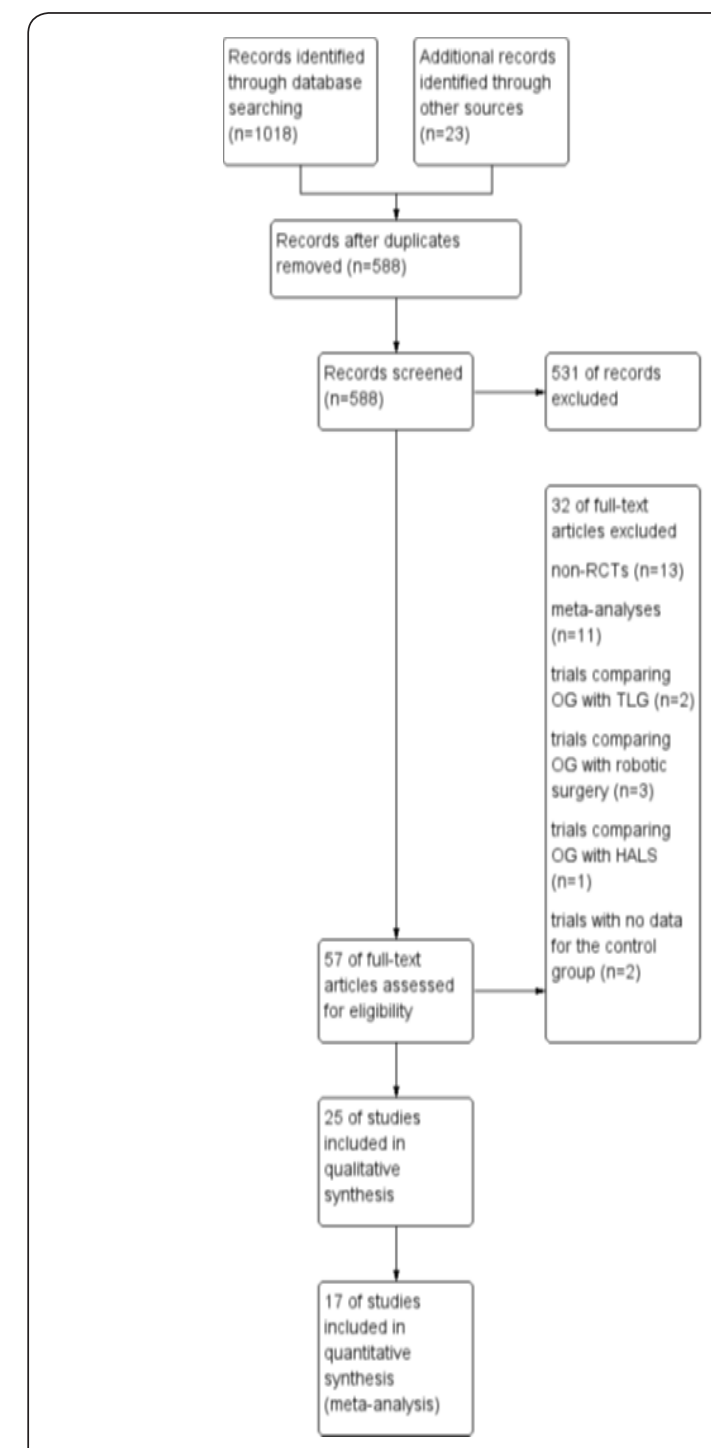

Figure 1: Flow chart of the identification and inclusion of studies. HALS: Hand-Assisted Laparoscopic Surgery; OG: Open Gastrectomy; RCTs: Randomized Controlled Trials; TLG: Total Laparoscopic Gastrectomy. 


\section{Cancer Therapy \& Oncology International Journal}

\section{Trials included in this Meta-Analysis}

Seventeen trials compared laparoscopy-assisted gastrectomy to open gastrectomy for gastric cancer were included in this meta-analysis [18-23,70-80]. All trials were published between 2002 and 2019. Sixteen of the included studies were reported by eastern authors (Japan and Korea) [18-23,70-79], whereas the seventeenth was reported from western country (Italy) [80]. The total numbers of patients included were 5198, of whom 2592 underwent LAG and 2606 underwent OG as the primary operative intervention. Six of the trials were multi-center RCTs $[70,72,73,75,76,78]$, and the other eleven trials were singlecenter RCTs $[18-23,71,74,77,79,80]$. Sixteen of the trials were two-armed RCTs $[18-23,70-78,80]$, and the other trial is fourarmed [79]. Two of the arms involved laparoscopic surgery (fast-track laparoscopic gastrectomy versus standard procedure laparoscopic gastrectomy) and the other two arms involved open surgery (fast-track laparoscopic gastrectomy versus standard procedure laparoscopic gastrectomy).

Table 1: The characteristics of the included studies.

\begin{tabular}{|c|c|c|c|c|c|c|c|c|c|c|}
\hline Year & $\begin{array}{l}\text { Coun- } \\
\text { try }\end{array}$ & center & $\begin{array}{l}\text { Number } \\
\text { random- } \\
\text { ized }\end{array}$ & $\begin{array}{l}\text { post-random- } \\
\text { ization drop- } \\
\text { outs }\end{array}$ & $\begin{array}{c}\text { Cases } \\
\text { LG/OG }\end{array}$ & $\begin{array}{c}\text { type of gastrec- } \\
\text { tomy }\end{array}$ & $\begin{array}{c}\text { Extent of } \\
\text { lymph- } \\
\text { adenectomy }\end{array}$ & Reconstruction & $\begin{array}{l}\text { Follow-up } \\
\text { (months) }\end{array}$ & $\begin{array}{l}\text { Matching } \\
\text { criteria }\end{array}$ \\
\hline 2019 & China & $\begin{array}{l}\text { multi-cen- } \\
\text { ter }\end{array}$ & 446 & $4(1 \%)$ & $222 / 220$ & DG(418), TG(24) & D2 (mainly) & $\begin{array}{l}\text { Billroth I(187), } \\
\text { Billroth II (202) or } \\
\text { Roux-en-Y(52) and } \\
\text { others(1) }\end{array}$ & $\begin{array}{c}36 \text { (results } \\
\text { pending) }\end{array}$ & $\begin{array}{c}1,2,3,4,5 \\
6,7,8,9 \\
10,11,12\end{array}$ \\
\hline 2018 & China & $\begin{array}{l}\text { single } \\
\text { center }\end{array}$ & 322 & $0(0 \%)$ & $162 / 160$ & $\begin{array}{c}\mathrm{DG}(196), \mathrm{PG}(18), \\
\mathrm{TG}(108)\end{array}$ & D2 & $\begin{array}{l}\text { Esophagogastrec- } \\
\text { tomy (18), Billroth } \\
\text { I (12), Billroth II } \\
\text { (184), and Roux- } \\
\text { en-Y (108) }\end{array}$ & $\begin{array}{l}60 \text { (results } \\
\text { pending) }\end{array}$ & $\begin{array}{c}1,2,3,4 \\
5,6,7,9 \\
10,11,12 \\
13\end{array}$ \\
\hline 2018 & Korea & $\begin{array}{l}\text { multi-cen- } \\
\text { ter }\end{array}$ & 204 & $8(4 \%)$ & $100 / 96$ & $\mathrm{DG}$ & D2 & $\begin{array}{c}\text { Billroth I/II or } \\
\text { Roux-en-Y }\end{array}$ & $\begin{array}{c}\text { Median } \\
38.2\end{array}$ & $\begin{array}{c}1,2,3,6 \\
7,13\end{array}$ \\
\hline 2017 & Japan & $\begin{array}{l}\text { multi-cen- } \\
\text { ter }\end{array}$ & 921 & $9(1 \%)$ & $457 / 455$ & $\begin{array}{c}\text { DG(675), } \\
\text { PPG(236), TG(1) }\end{array}$ & $\begin{array}{c}\mathrm{D} 1(10), \\
\mathrm{D} 1+(666) \\
\text { D2(227), } \\
\mathrm{D} 2+(9)\end{array}$ & $\begin{array}{c}\text { Roux-en-Y(240), } \\
\text { Billroth I } \\
\text { (432),Billroth II } \\
\text { (4), Gastro-Gastro } \\
\text { (236) }\end{array}$ & 60 & $\begin{array}{c}1,2,3,6,8 \\
9,10,11 \\
12\end{array}$ \\
\hline 2016 & Japan & $\begin{array}{l}\text { single } \\
\text { center }\end{array}$ & 64 & $1(2 \%)$ & $31 / 32$ & DG & $\begin{array}{l}\text { Standardized } \\
\text { according } \\
\text { to the JCGC } \\
\text { 2nd English } \\
\text { edition }\end{array}$ & $\begin{array}{l}\text { Standardized } \\
\text { according to the } \\
\text { JCGC } 2 \text { nd English } \\
\text { edition }\end{array}$ & median 63 & $\begin{array}{c}1,2,3,4,5 \\
6,7,9,11\end{array}$ \\
\hline 2016 & $\begin{array}{l}\text { South } \\
\text { Korea }\end{array}$ & $\begin{array}{l}\text { multi-cen- } \\
\text { ter }\end{array}$ & 1416 & $32(2 \%)$ & $686 / 698$ & $\begin{array}{c}\text { DG(1360), } \\
\text { TG(23), others(1) }\end{array}$ & $\begin{array}{c}\mathrm{D} 1+\alpha(2) \\
\mathrm{D} 1+\beta(549) \\
\mathrm{D} 2(832)\end{array}$ & $\begin{array}{c}\text { Billroth I(935),- } \\
\text { Billroth II(395), } \\
\text { and Roux-en-Y(53) }\end{array}$ & 60 & $\begin{array}{c}1,2,3,4 \\
5,6,7,9 \\
10,12\end{array}$ \\
\hline 2016 & China & $\begin{array}{l}\text { multi-cen- } \\
\text { ter }\end{array}$ & 1056 & $17(2 \%)$ & $519 / 520$ & DG(1015),TG(24) & D2 (mainly) & $\begin{array}{c}\text { Billroth I } \\
\text { (565),Billroth II } \\
\text { (339), Roux-en-Y } \\
\text { (92), and others } \\
\text { (43) }\end{array}$ & NS & $\begin{array}{c}1,2,3,5 \\
6,7,8,9 \\
11,12\end{array}$ \\
\hline 2015 & China & $\begin{array}{l}\text { single } \\
\text { center }\end{array}$ & 296 & $26(9 \%)$ & $128 / 142$ & $\begin{array}{c}\mathrm{DG}(148), \mathrm{PG}(41) \\
\mathrm{TG}(81)\end{array}$ & D2 & Billroth I/II & 1 & $\begin{array}{c}1,2,3,6,7 \\
8,9,11\end{array}$ \\
\hline 2014 & Japan & $\begin{array}{l}\text { multi-cen- } \\
\text { ter }\end{array}$ & 26 & $0(0 \%)$ & $13 / 13$ & DG & $\begin{array}{c}\mathrm{D} 1+(17), \mathrm{D} 2 \\
(9)\end{array}$ & $\begin{array}{l}\text { Billroth I (23), } \\
\text { Roux-en-Y (3) }\end{array}$ & 1 month & $\begin{array}{l}1,2,3,5,6, \\
7,9,11,12\end{array}$ \\
\hline 2013 & Japan & $\begin{array}{l}\text { single } \\
\text { center }\end{array}$ & 40 & $0(0 \%)$ & $20 / 20$ & DG & D1(38), D2(2) & Billroth I & at least 60 & $\begin{array}{c}1,2,3,6,7 \\
9,10,12\end{array}$ \\
\hline 2013 & $\begin{array}{l}\text { South } \\
\text { Korea }\end{array}$ & $\begin{array}{l}\text { single } \\
\text { center }\end{array}$ & 164 & $0(0 \%)$ & $82 / 82$ & DG & D2 & $\begin{array}{l}\text { Billroth I(155), } \\
\text { Billroth II (8) or } \\
\text { Roux-en-Y(1) }\end{array}$ & $\begin{array}{l}\text { Median: } \\
74.3\end{array}$ & $\begin{array}{c}1,2,3,6,7 \\
9,11,12 \\
13\end{array}$ \\
\hline 2012 & China & $\begin{array}{l}\text { single } \\
\text { center }\end{array}$ & 88 & $6(7 \%)$ & $41 / 41$ & DG & $\begin{array}{l}\text { Standardized } \\
\text { according to } \\
\text { the JCGC }\end{array}$ & $\begin{array}{l}\text { Billroth I(57),Bill- } \\
\quad \text { roth II(25) }\end{array}$ & 1 month & $\begin{array}{c}1,2,3,6,7 \\
12,13\end{array}$ \\
\hline
\end{tabular}




\section{Cancer Therapy \& Oncology International Journal}

\begin{tabular}{|c|c|c|c|c|c|c|c|c|c|c|}
\hline 2011 & China & $\begin{array}{l}\text { single } \\
\text { center }\end{array}$ & 123 & $27(22 \%)$ & $49 / 47$ & $\begin{array}{c}\mathrm{DG}(36), \mathrm{PG}(55), \\
\mathrm{TG}(5)\end{array}$ & D2 & $\begin{array}{c}\text { Billroth I/II } \\
\text { esophagogastros- } \\
\text { tomy and esopha- } \\
\text { geal jejunostomy }\end{array}$ & Mean 22.1 & $\begin{array}{c}1,2,3,5,6, \\
7,8,9,10, \\
11,13\end{array}$ \\
\hline 2005 & $\begin{array}{l}\text { South } \\
\text { Korea }\end{array}$ & $\begin{array}{l}\text { single } \\
\text { center }\end{array}$ & 47 & $0(0 \%)$ & $24 / 23$ & DG & D2 & Billroth I & Median 14 & $\begin{array}{c}1,2,3,5 \\
6,7,9,10 \\
11,12\end{array}$ \\
\hline 2005 & Italy & $\begin{array}{l}\text { single } \\
\text { center }\end{array}$ & 70 & $11(16 \%)$ & $30 / 29$ & DG & $\begin{array}{c}\text { D1 (18), D2 } \\
(41)\end{array}$ & $\begin{array}{l}\text { Billroth II (12), } \\
\text { Roux-en-Y (47) }\end{array}$ & $\begin{array}{c}\text { LAG 55, OG } \\
60\end{array}$ & $\begin{array}{c}1,2,4,6,8, \\
11,12\end{array}$ \\
\hline 2005 & Japan & $\begin{array}{l}\text { single } \\
\text { center }\end{array}$ & 28 & $0(0 \%)$ & $14 / 14$ & DG & $\mathrm{D} 1+\alpha$ & Billroth I & $\begin{array}{c}\mathrm{L} \text { G 39, OG } \\
45\end{array}$ & $\begin{array}{c}1,2,3,5,6, \\
7,11,12\end{array}$ \\
\hline 2002 & Japan & $\begin{array}{l}\text { single } \\
\text { center }\end{array}$ & 28 & $0(0 \%)$ & $14 / 14$ & DG & $\mathrm{D} 1+\alpha$ & Billroth I & Median 26 & $\begin{array}{c}1,2,3,5 \\
6,7,9,10 \\
11,12\end{array}$ \\
\hline
\end{tabular}

All trials included patients suffering from adenocarcinoma of the stomach. Eight trials included patients with early gastric cancer [18-23,73-75], five trials reported on patients with advanced gastric cancer [20,70-72,76], and four trials included a wide range of cancer staging (early or advanced gastric cancer) [77-80]. Ten of the trials included patients in whom distal gastrectomy was performed [18,19,21-23,72,74,78-80]. Both distal gastrectomy and proximal gastrectomy were performed in three trials $[70,75,76]$. DG, PG and TG were performed in four trials $[20,71,73,77]$. The types of lymph node dissection included D1, modified D2 lymphadenectomy (D1+), and D2 lymphadenectomy. The reconstruction types included Billroth I/II, Esophagogastrostomy, Esophageal jejunostomy, Gastrogastro, Roux-en-y, and others. The median follow-up for all trials ranged from 1 to 74.3 months. The characteristics of the included studies were summarized on table 1 on supplementary file.

\section{Risk of Bias in Included Trials}

Eleven trials used adequate random sequence $[18,19,21,71$ 87], and six tria'ls did not define the exact method of randomization, so the risk of bias in those trials was unclear $[20,22,23,70,79,80]$. Allocation concealment risk was low in twelve trials $[18,19,22,23,70-72,74-76,78,80]$, unclear in four $[20,21,77,79]$, and high in one trial [73]. Blinding of participants and personnel was difficult to perform due to the nature of the intervention, and the risk of bias was high in thirteen trials $[19-23,70,72-74,76,77,79,80]$, unclear in three trials $[71,75,78]$, and low in only one trial [18]. Six of the trials were low risk of detection bias $[19,72-75,79]$, high in nine trials $[18,20-23,70,76,77,80]$, and unclear in two trials $[71,78]$. We classified eleven trials at low risk of attrition bias because either they described no post-randomization drop-outs $[18,19,21$ $23,71,78]$, or they used modified intention-to-treat analysis [70,72,74-76] and six trials were at high risk of attrition bias because they had post-randomization drop-outs, which were likely to affect the effect estimate $[20,73,77,79,80]$. Reporting bias was low in fourteen trials [19,21-23,70-73,75-80], high in one trial [18], and unclear in studies reported by Cai et al and Yamashita et al because the study protocol for these trials was not available $[20,74]$. in the trial reported by lee et al, a more extensive procedure (subtotal gastrectomy) was performed in the OG group compared to LAG group, this could favors the LAG in term of decreased complications, but favors OG group in terms of decreased mortality and tumor recurrence, so, the other risk of bias was high in this trial [21]. In one trial, surgeons are different in both groups, and there is no information available regarding the learning curve and thus unclear risk of bias [20]. We did not detect any other source of bias in the remaining trials $[18,19,22,23,70-80]$. The risk of bias for included trials was summarized on (Figure 2).

\section{Meta-analyses of Operative Outcomes}

\section{Operative Time}

Data on operative time was available from all included trials [18-23,70-80]; these trials shows that the operative time was 67.90 min longer in the LAG group than in the OG group (MD $67.90,95 \%$ CI 54.51 to $81.30, \mathrm{P}<0.00001)$; with significant heterogeneity among trials $\left(\mathrm{I}^{2}=96 \%, \mathrm{P}<0.00001\right)$. because lymphadenectomy is a time-consuming procedure in gastric cancer surgery, we carried out subgroup analysis based on extend of lymphadenectomy, but, statistically significant heterogeneity was still identified in the subgroups. In D1+ lymphadenectomy ,the overall effect size of the mean operative time was $93.66 \mathrm{~min}$ longer in LAG group than in the OG group (MD 93.66, 95\% CI 9.17 to $178.14, \mathrm{P}<0.00001$ ) and it was 65.13 min longer in $\mathrm{D} 2$ lymphadenectomy subgroup(MD 65.13, 95\% CI 43.02 to 87.23 , $\mathrm{P}<0.00001$ ) and 68.76 min longer in the mixed D1+ with D2 lymphadenectomy subgroup(MD 68.76, 95\% CI 46.09 to 91.43 , $\mathrm{P}<0.00001)$. Test for subgroup differences: $\mathrm{Chi}^{2}=0.42, \mathrm{df}=2(\mathrm{P}$ $=0.81), \mathrm{I}^{2}=0 \%($ Figure $3 \mathrm{~A})$. 


\section{Cancer Therapy \& Oncology International Journal}

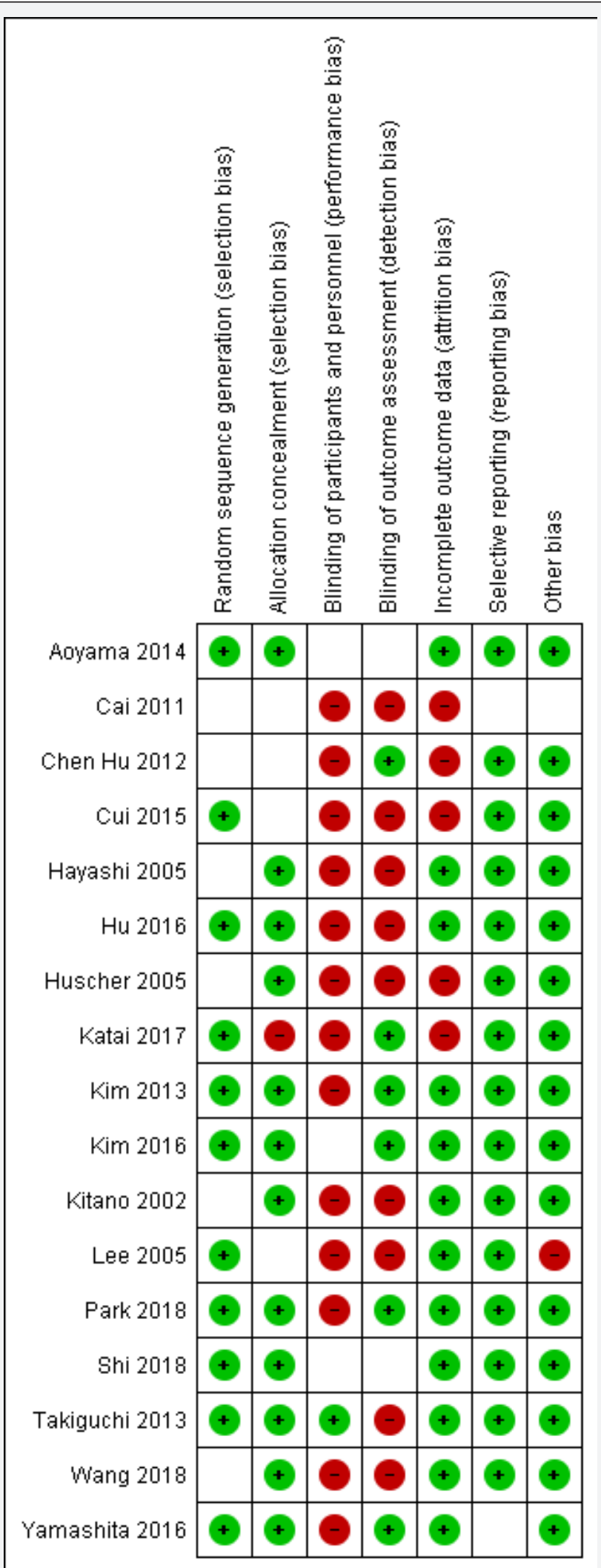

Figure 2: Risk of bias summary: review authors' judgements about each risk of bias item for each included study. The green color indicates low risk of bias. The red color indicates high risk of bias. Unclear risk of bias is indicated by empty cell. 


\section{Cancer Therapy \& Oncology International Journal}

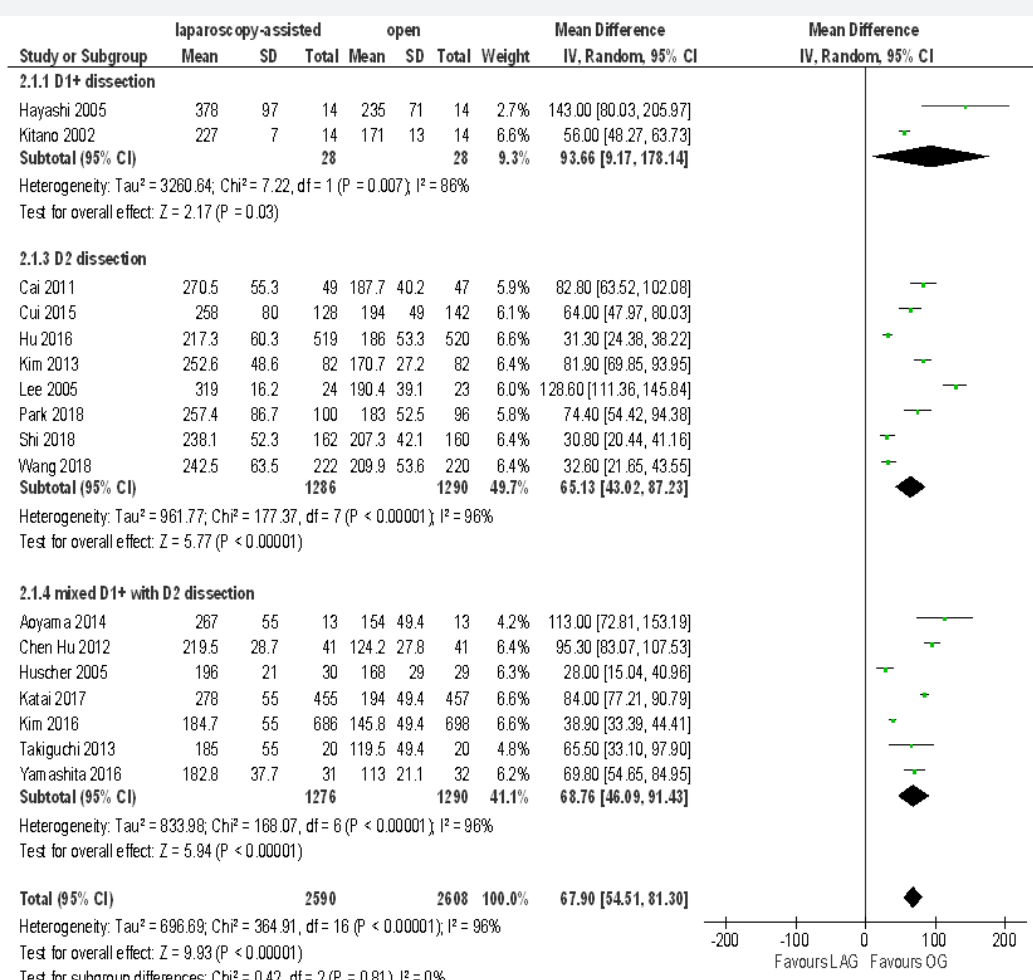

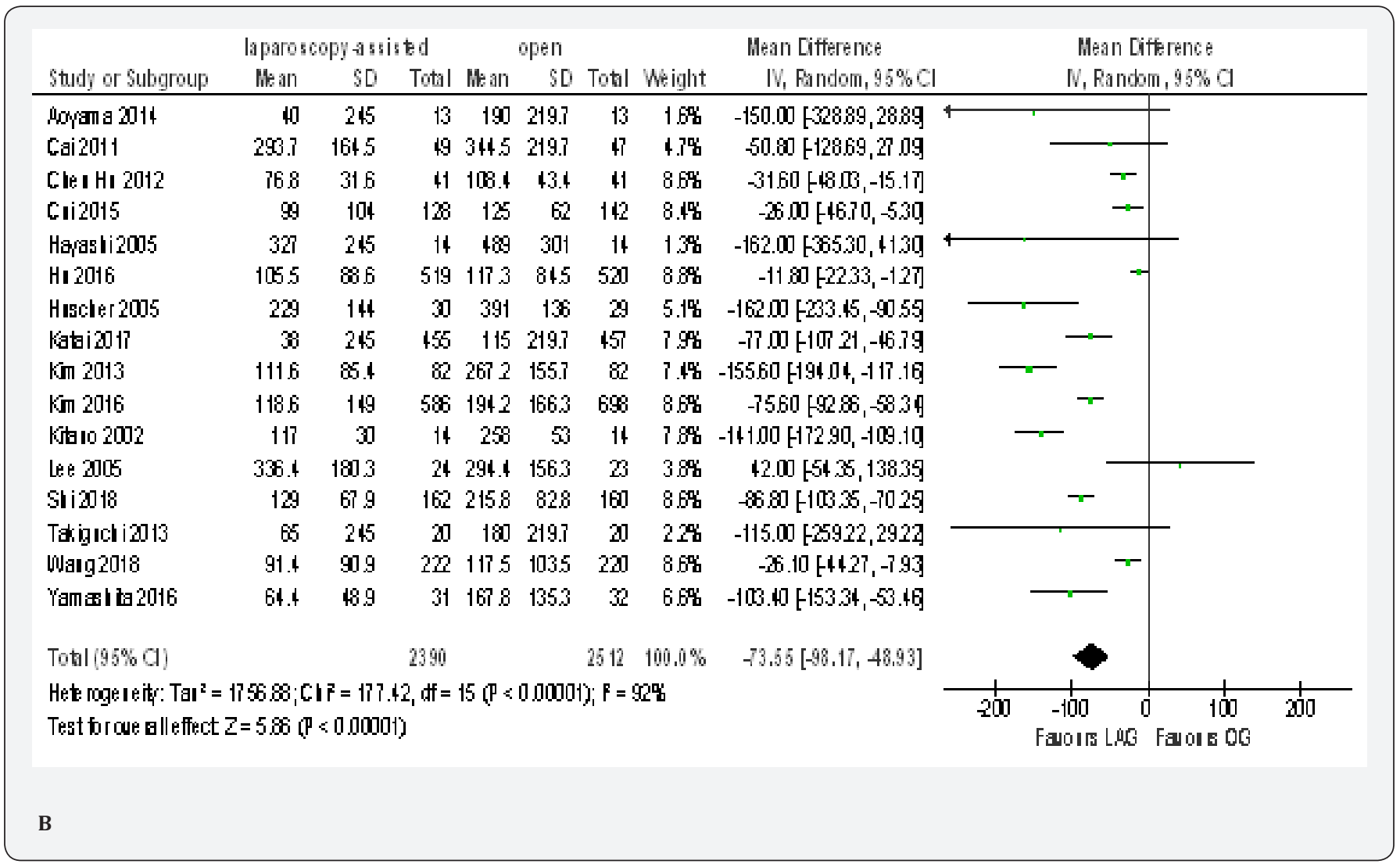




\begin{tabular}{|c|c|c|c|c|c|c|c|c|c|}
\hline Study or Subaroup & \multicolumn{2}{|c|}{ laparoscopy-assised } & open & Total & Weight & $\begin{array}{c}\text { Odds Ratio } \\
\text { 1.1- } \mathrm{H}, \text { Random, } 95 \% \mathrm{Cl} \\
\end{array}$ & \multicolumn{3}{|c|}{$\begin{array}{c}\text { Odds Fatio } \\
\text { I.- } \mathrm{H} \text {, Random, } 95 \% \mathrm{Cl}\end{array}$} \\
\hline Aoyama 2014 & 0 & 13 & 0 & 13 & & Not estmable & & & \\
\hline Cui 2015 & 0 & 128 & 0 & 142 & & Not estmable & & & \\
\hline Hayashi 2005 & 0 & 14 & 0 & 14 & & Not estmable & & & \\
\hline Hบ 2016 & 14 & 519 & 14 & 520 & $22.8 \%$ & $100[0.47,2.12]$ & & & \\
\hline Katai 2017 & 3 & 455 & 1 & 457 & $2.5 \%$ & $303[0.31,2920]$ & & & \\
\hline $\operatorname{kim} 2013$ & 0 & 82 & 0 & 82 & & Not estimable & & & \\
\hline $\operatorname{kim} 2016$ & 5 & 686 & 8 & 698 & $10.2 \%$ & $0.63[021,195]$ & & - & \\
\hline Shi 2018 & 34 & 162 & 49 & 160 & $50.1 \%$ & $0.60[0,36,100]$ & & 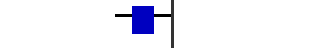 & \\
\hline Takjguchi 2013 & 0 & 20 & 0 & 20 & & Not estmable & & & \\
\hline WVang 2018 & 9 & 22 & 9 & 220 & $14.4 \%$ & $099[0,39,254]$ & & - & \\
\hline Tdal $(95 \% \mathrm{Cl})$ & & 2301 & & 2326 & $100.9 \%$ & $0.76[0.53,1.99]$ & & & \\
\hline Total events & 65 & & 81 & & & & & & \\
\hline $\begin{array}{l}\text { Heterogenety. Taı }{ }^{2}= \\
\text { Tes br owerall effed: }\end{array}$ & $\begin{array}{l}0.00 ; \text { Chi }^{2}=3 \\
Z=150(P=0\end{array}$ & $f=4(P$ & $=0.53) \mathrm{I}^{2}$ & $=0 \%$ & & & $\stackrel{\longmapsto}{\circ .01}$ & $\begin{array}{llr}1 & 1 \\
0.1 & 1 & 10 \\
\text { Fawours LAOS Fawours } 00\end{array}$ & 100 \\
\hline & & & & & & & & & \\
\hline
\end{tabular}

\section{Intra-operative Blood Loss}

Sixteen trials totaling 4902 patients provided data regarding intra-operative estimated blood loss [18-23,70, 71,73-80]. The combined results of these sixteen trials showed significantly lower estimated blood loss in LAG compared to OG groups (MD $-73.55,95 \%$ CI -98.17 to $-48.93, \mathrm{P}<0.00001)$ with significant heterogeneity among studies $\left(\mathrm{I}^{2}=92 \%, \mathrm{P}<0.00001\right)$ (Figure 3B).

\section{Number of Transfused Patients}

Data from nine trials with 4627 patients were available to calculate odd ratio for number of transfused patients $[18,19,22,70,71,73,75-78]$. Compared with OG group, the LAG group showed no statistically significant difference (OR 0.76, $95 \%$ CI 0.53 to $1.09, \mathrm{P}=0.13$ ) with no heterogeneity among trials $\left(\mathrm{I}^{2}=0 \%, \mathrm{P}=0.53\right.$ ) (Figure $3 \mathrm{C}$ ).

\section{Meta-analysis of post-operative outcomes}

\section{Post-operative analgesic consumption}

Analgesic consumption was reported by only four included studies with 425 patients [21-23, 71]. These trials showed lower frequency of analgesic consumption in LAG group than in the OG group (MD -1.33, 95\% CI -1.62 to $-1.04, \mathrm{P}<0.00001$ ) . With minimal heterogeneity among studies $\left(\mathrm{I}^{2}=20 \%, \mathrm{P}=0.29\right)$ (Figure 4A).

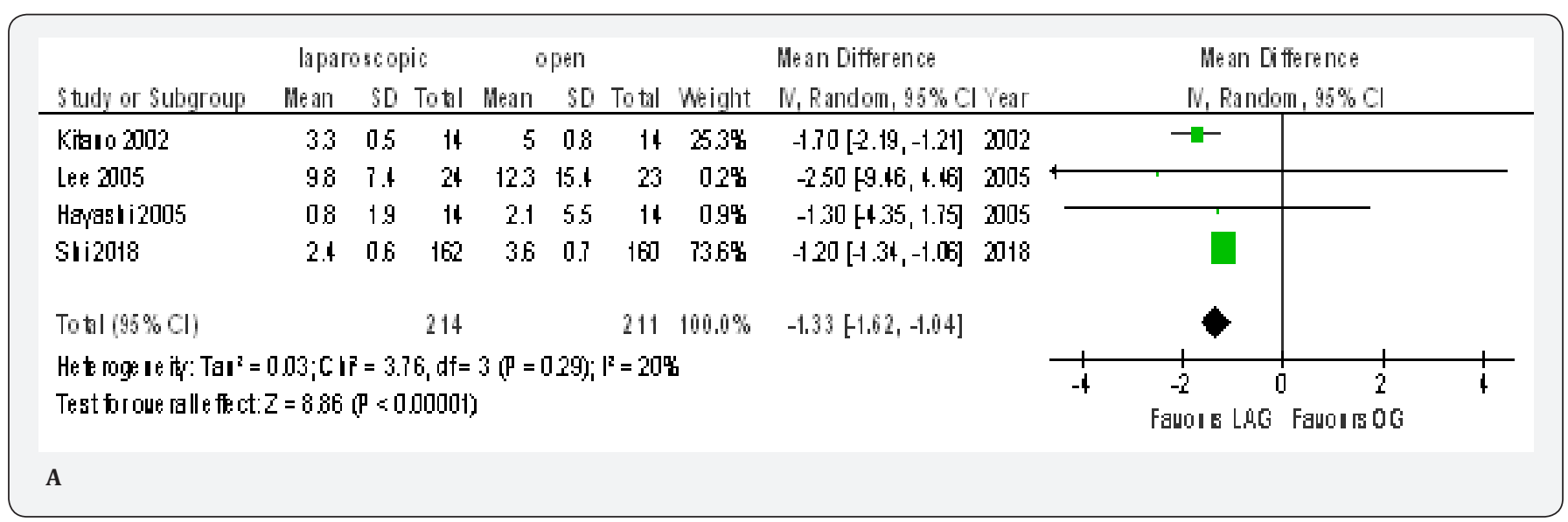




\section{Cancer Therapy \& Oncology International Journal}

\section{Time to first Ambulation}

Data from six included papers included 2197 patients was available to calculate the weighted mean difference for the time to ambulation $[20,23,70,71,76,77]$. The time was shorter in the LAG group than in the OG group (MD $-0.49,95 \%$ CI -0.89 to -0.09 , $\mathrm{P}<0.02)$ with significant heterogeneity among trials $\left(\mathrm{I}^{2}=95 \%\right.$, $\mathrm{P}<0.00001$ ). (Figure 4B).

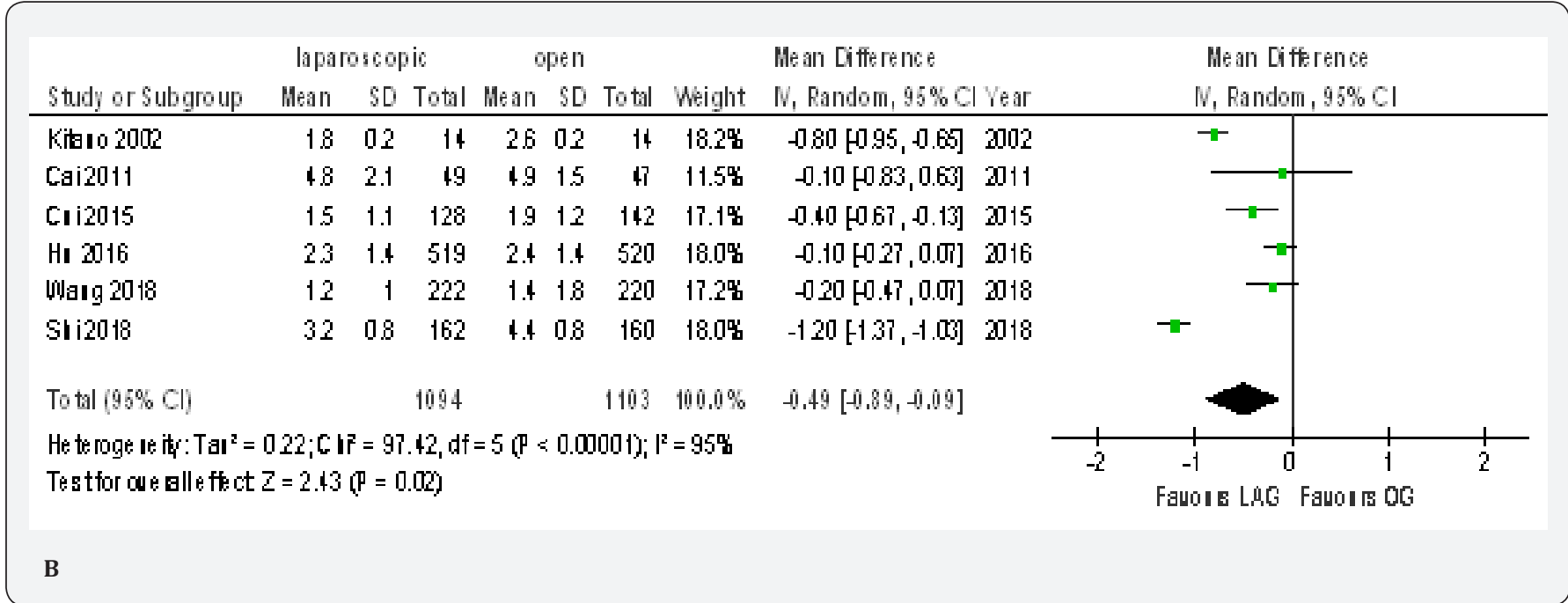

\section{Time to first Flatus}

Thirteen studies included 3533 patients reported the time to first flatus [18-23,70,71,73,74,76,77,79]. Meta-analysis demonstrated significantly shorter time to first flatus in the LAG group than in the OG group(MD $-1.14,95 \% \mathrm{CI}-1.68$ to $-0.60, \mathrm{P}<$ $0.0001)$ with significant heterogeneity among studies $\left(\mathrm{I}^{2}=98 \%\right.$, $\mathrm{P}<0.00001$ ) (Figure 4C).

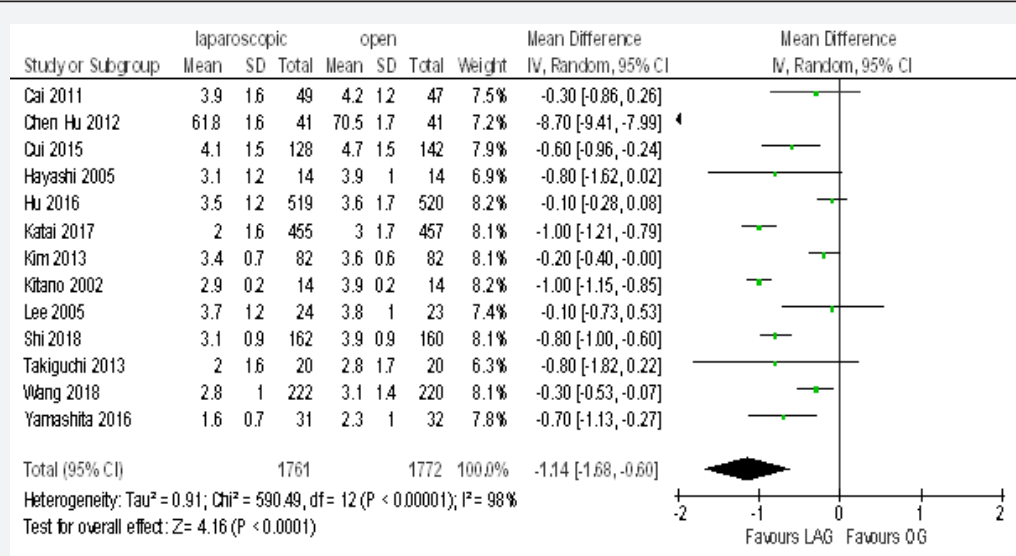

C

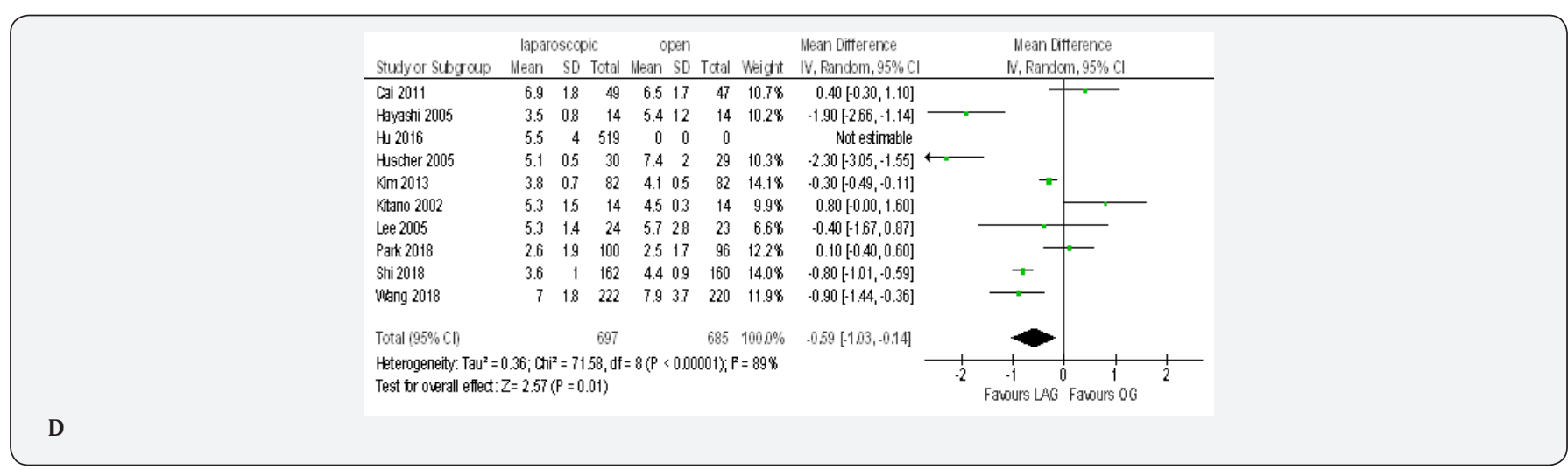




\section{Cancer Therapy \& Oncology International Journal}

\section{Time to first Oral Intake:}

Nine papers with 1382 patients reported the time to first oral intake [19-23,70-72,80]. Meta-analysis showed this time was shorter in the LAG group than in the OG group(MD -0.59 , $95 \%$ CI -1.03 to $-0.14, \mathrm{P}<0.01$ ) with substantial heterogeneity among papers $\left(\mathrm{I}^{2}=89 \%, \mathrm{P}<0.00001\right)$ (Figure $4 \mathrm{D}$ ).

\section{Length of Post-Operative Hospital Stay}

Fourteen trials with 3990 patients provided data on length of post-operative hospital stay [18-23,70-72,74-76, 79,80]. The overall WMD was 1.15 days , (MD -1.15, 95\% CI -1.90 to $-0.40, \mathrm{P}<$ 0.00001 ) in favor of laparoscopy. With substantial heterogeneity among trials $\left(\mathrm{I}^{2}=85 \%, \mathrm{P}<0.003\right.$ ) (Figure 4E).

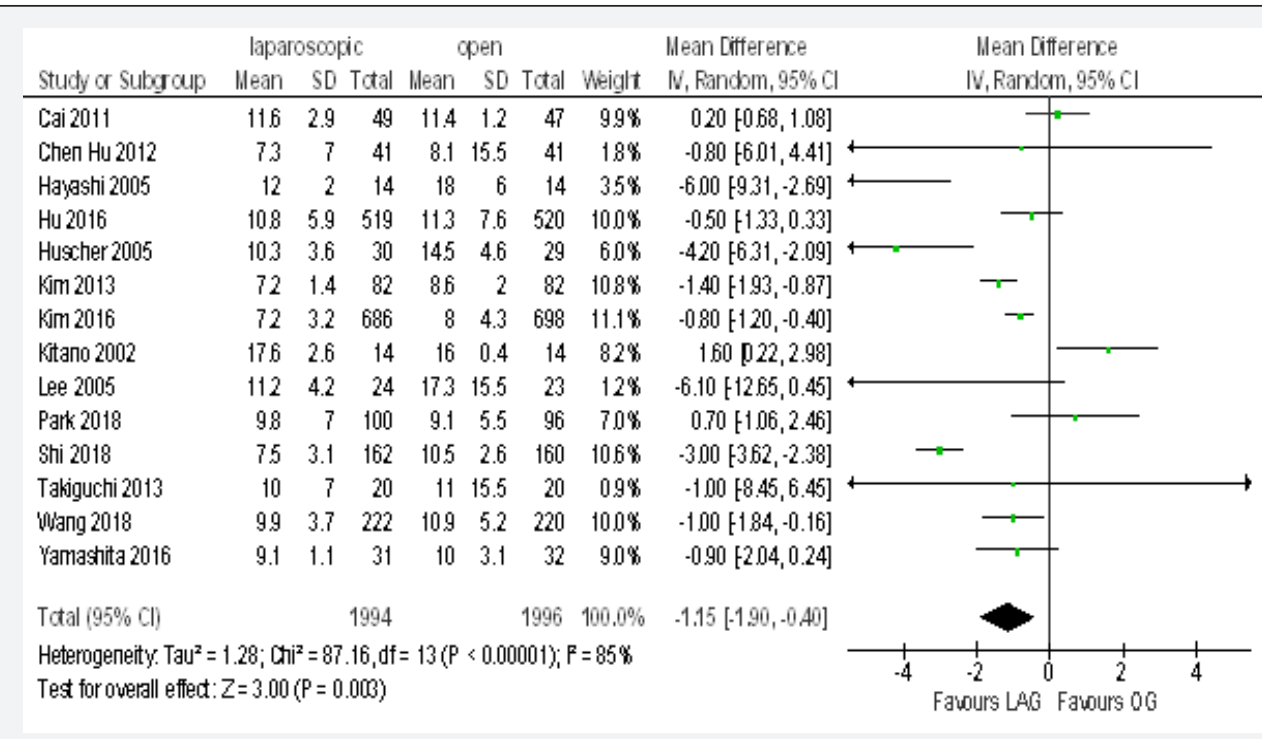

\section{Overall Post-Operative Morbidity}

The overall post-operative morbidity rates were reported in all included studies [18-23,70-80]. These studies demonstrated a significantly lower overall post-operative morbidity after LAG than after OG (OR $0.80,95 \%$ CI 0.65 to 0.99 ), $\mathrm{P}=0.04$ ), with minimal heterogeneity among studies $\left(\mathrm{I}^{2}=21 \%, \mathrm{P}=0.21\right)$
(Figure 4F). The subgroup analyses showed no difference in the incidence rate of major surgical complications such as ( abdominal abscess, anastomotic stenosis, anastomoptic leakage, gastroperesis, , ileus, intestinal obstruction, pancreatitis, pancreatic fistula, post-operative bleeding and wound infection) and pneumonia between the two groups.

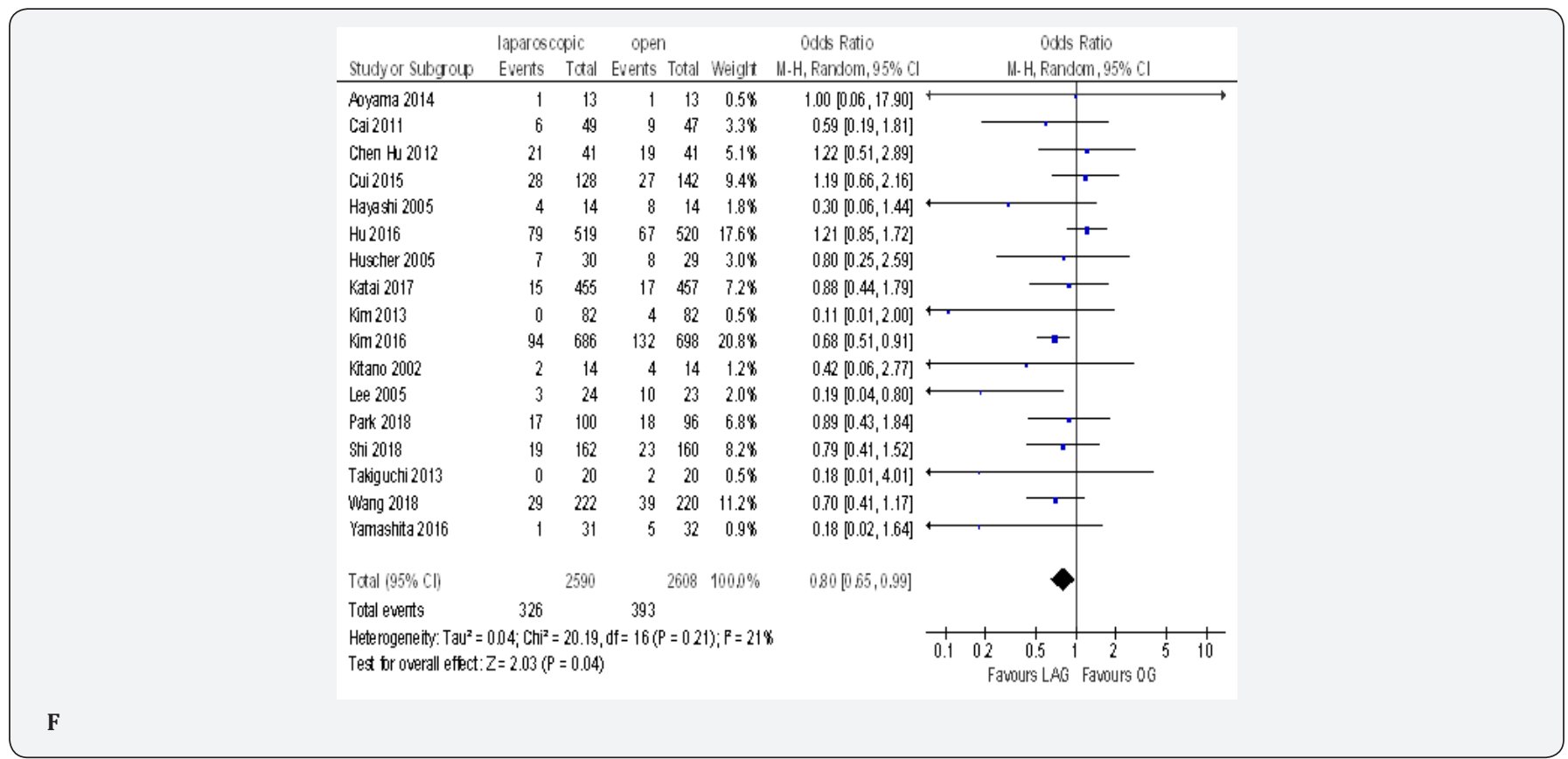




\section{Cancer Therapy \& Oncology International Journal}

\section{Incidence of Reoperation}

The reoperation incidence was reported in five papers with 4099 patients $[70,71,73,75,76]$. No difference in this parameter was found between LAG and OG groups (OR 0.87, 95\% CI 0.51 to $1.49, \mathrm{P}=0.62)$ with no heterogeneity among trials $\left(\mathrm{I}^{2}=0 \%, \mathrm{P}=\right.$ 0.88) (Figure 4G).

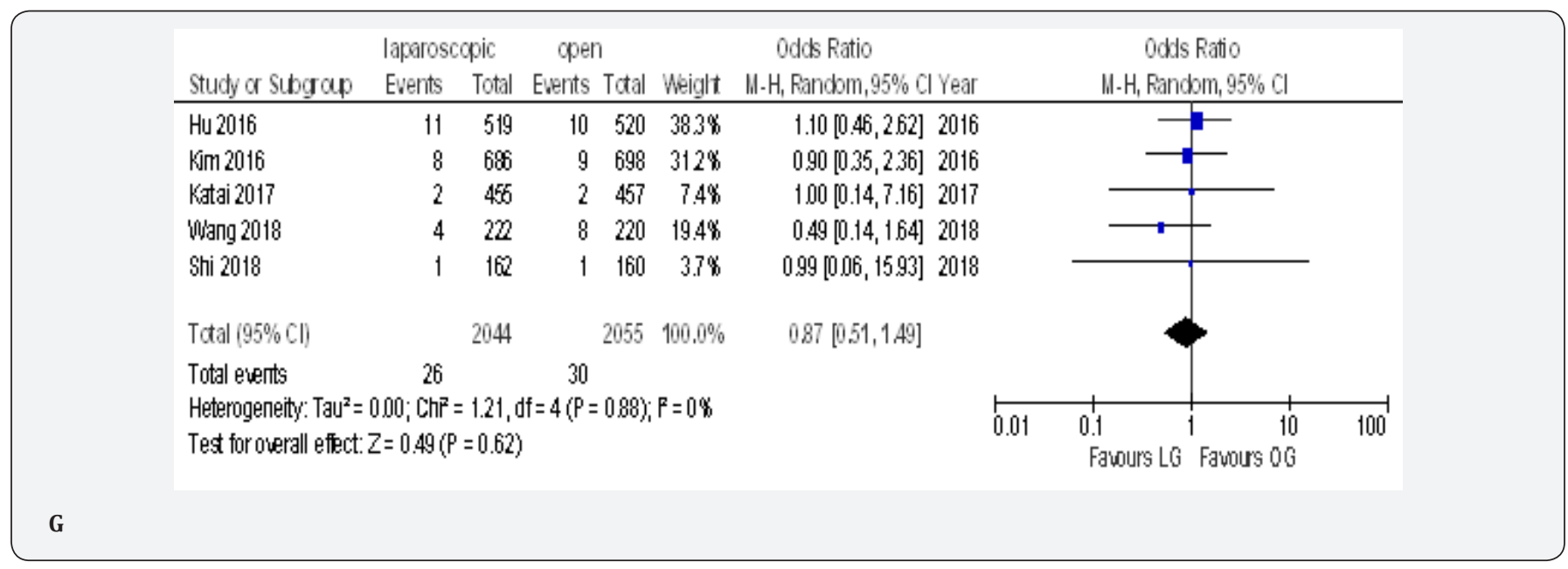

\section{Mortality}

Fifteen included trials reported short-term mortality [1822,70-80]. The meta-analysis revealed no differences between the two approaches (OR $0.84,95 \%$ CI 0.16 to $4.36, \mathrm{P}=0.84$ ) with no heterogeneity among trials $\left(\mathrm{I}^{2}=0 \%, \mathrm{P}=0.38\right.$ ) (Figure $4 \mathrm{H}$ ) (Figure 5).

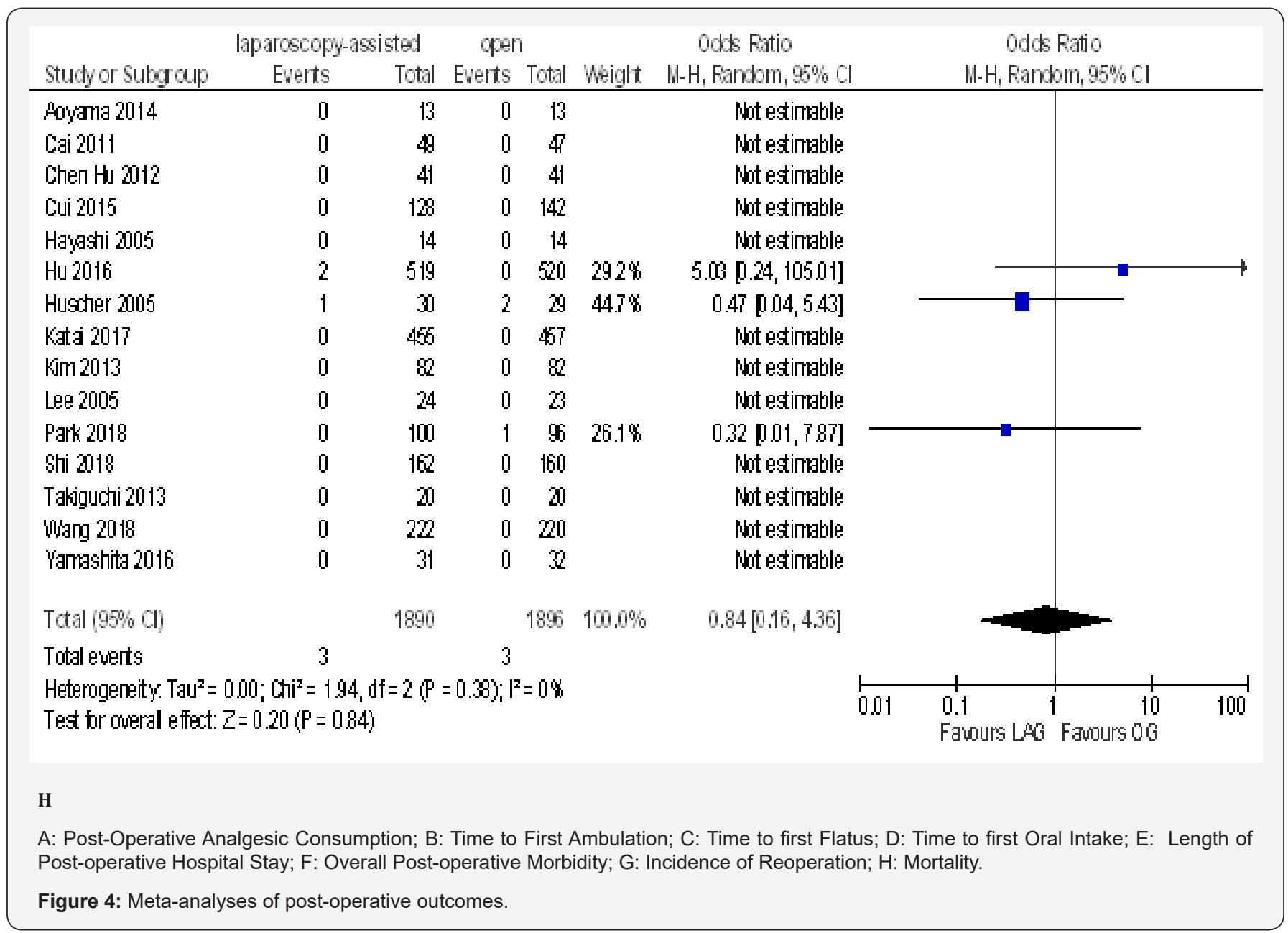




\section{Cancer Therapy \& Oncology International Journal}

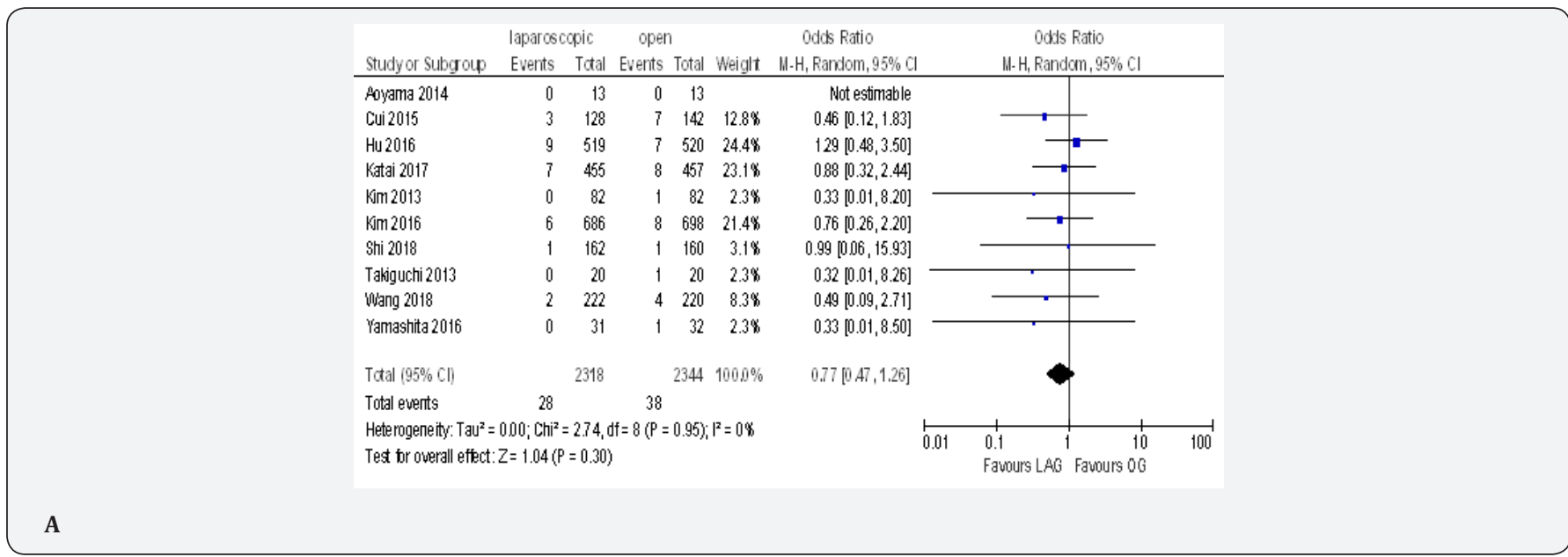

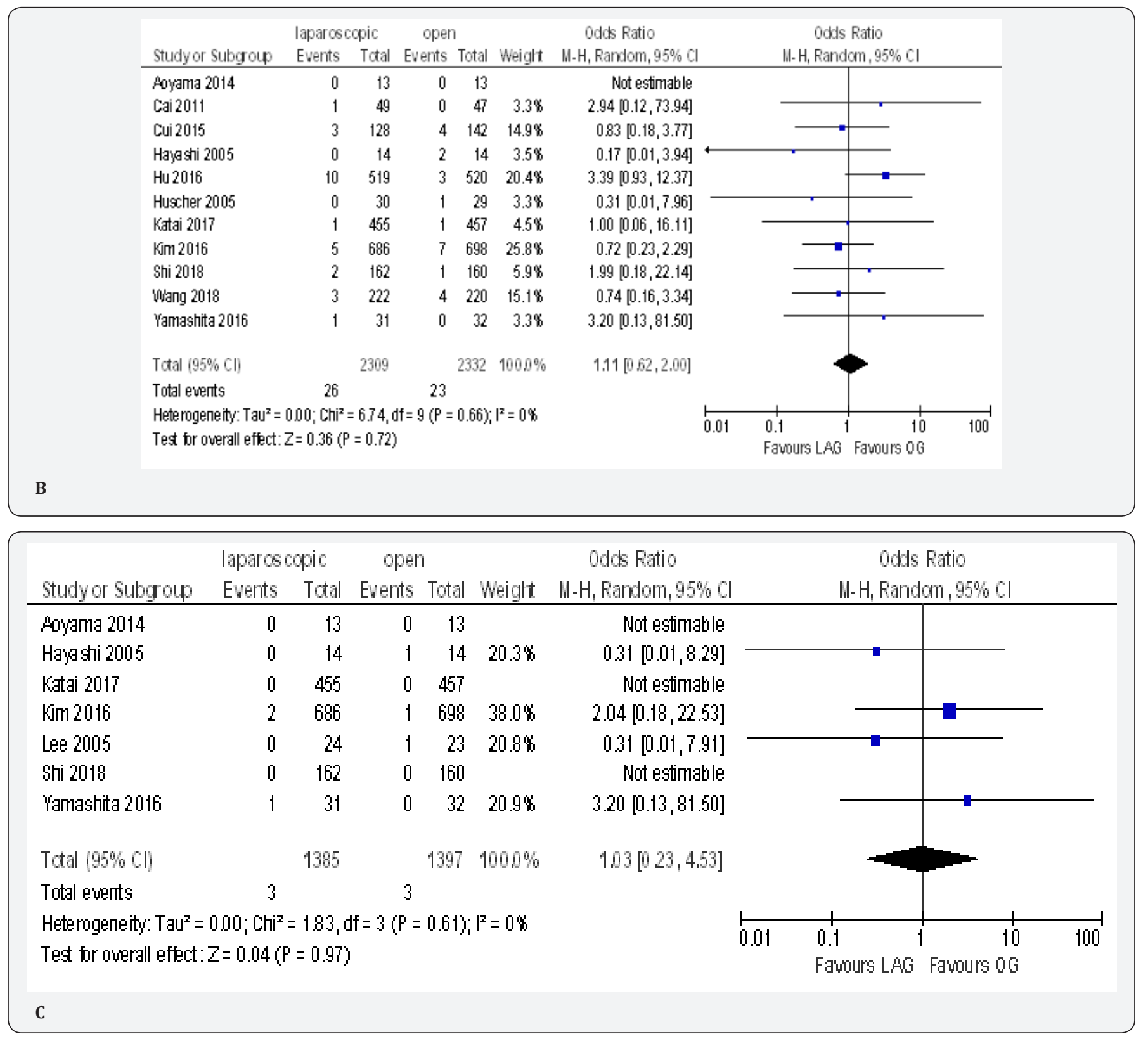




\section{Cancer Therapy \& Oncology International Journal}

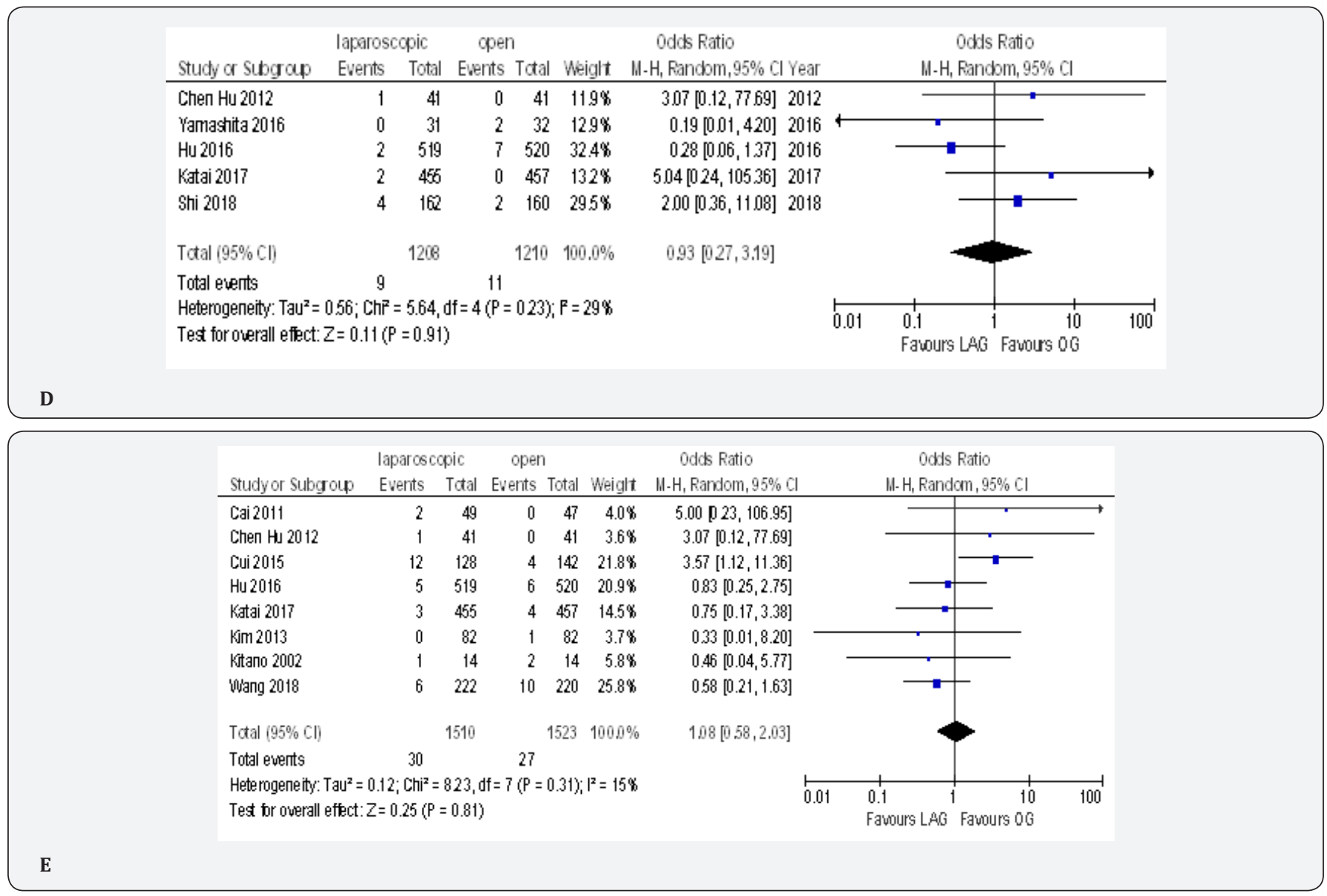

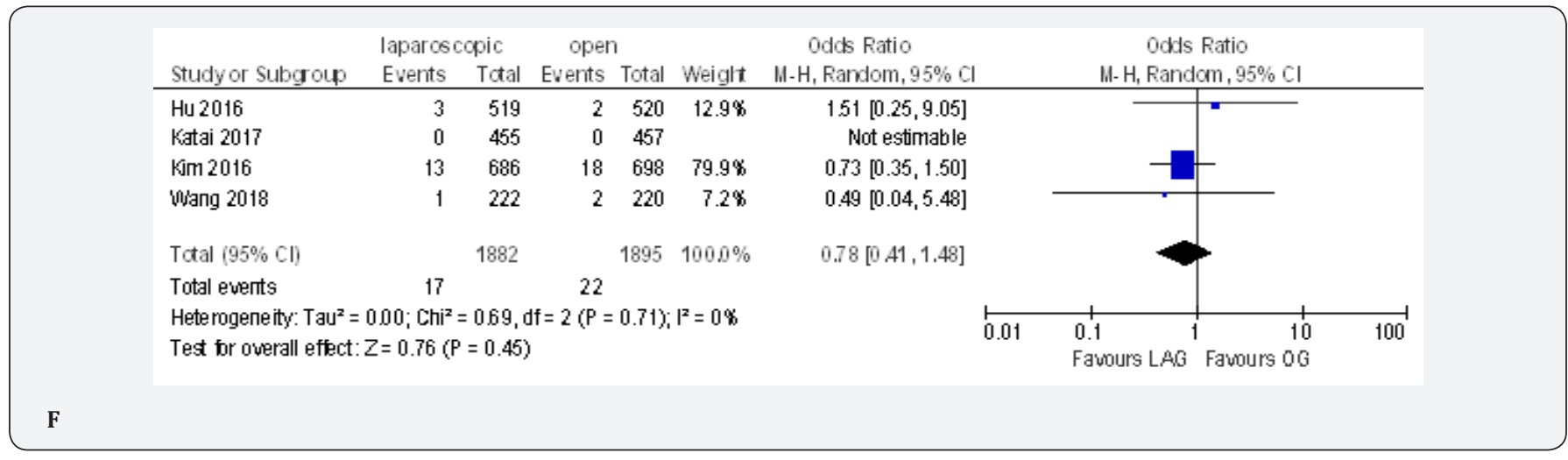

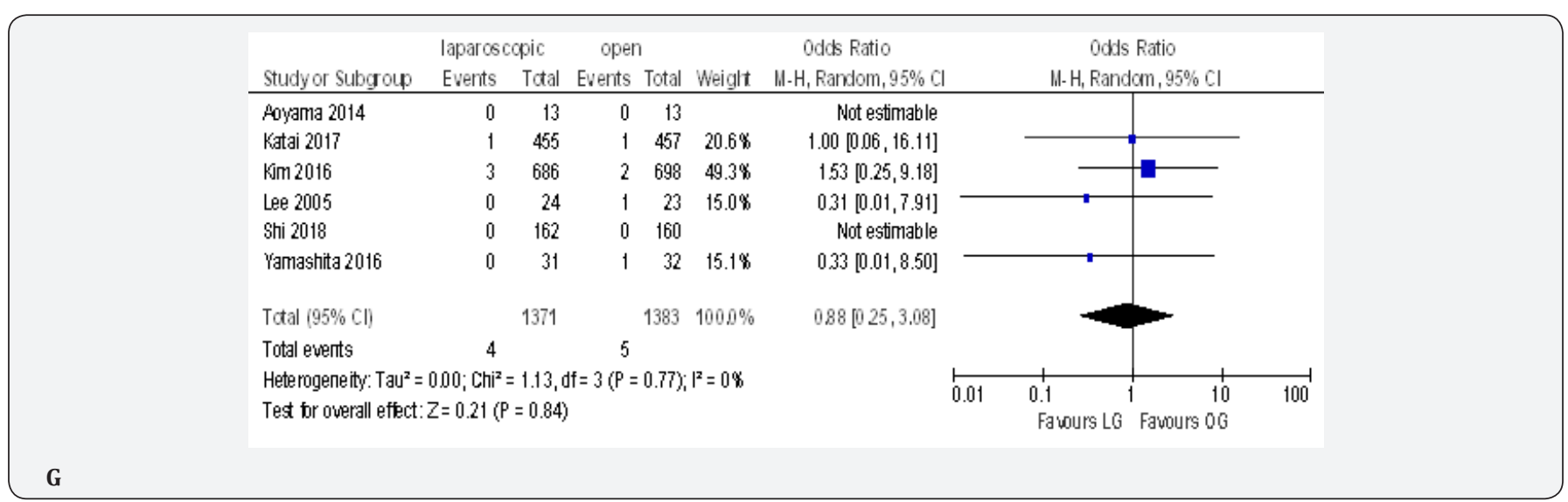




\section{Cancer Therapy \& Oncology International Journal}

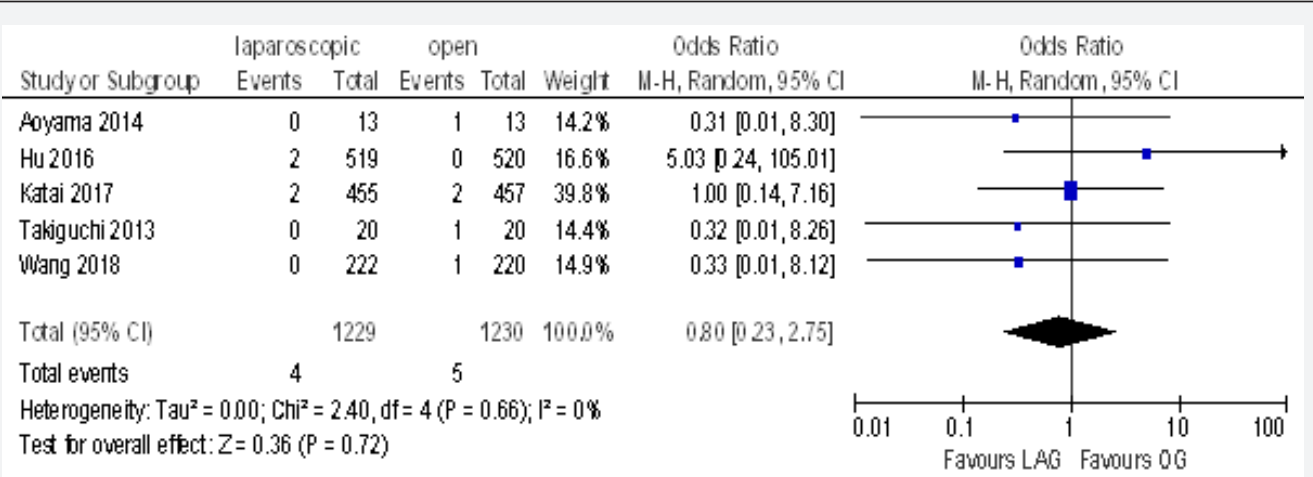

H

\begin{tabular}{|c|c|c|c|c|c|c|c|c|c|c|}
\hline Study or Subgroup & \multicolumn{2}{|c|}{ laparosoopac } & \multicolumn{2}{|c|}{ open } & \multicolumn{2}{|r|}{ Odds kătı } & \multicolumn{4}{|c|}{$\begin{array}{c}\text { Odds batlo } \\
\text { H. }-\mathrm{H} \text {, Random, } 95 \% \mathrm{Cl}\end{array}$} \\
\hline $\operatorname{kim} 2016$ & 1 & 686 & 0 & 698 & $100.0 \%$ & $306[0.12,75.17] 2016$ & & & & \\
\hline Shi 2018 & 0 & 162 & 0 & 160 & & Not estimable 2018 & & & & \\
\hline Tctal $(95 \% \mathrm{Cl})$ & & 848 & & 858 & $100.9 \%$ & $396[0.12,75.17]$ & & & & \\
\hline Total events & 1 & & 0 & & & & & & & \\
\hline $\begin{array}{l}\text { Heterogeneity: Not ar } \\
\text { Test for owerall effect }\end{array}$ & $\begin{array}{l}\text { icable } \\
Z=0.68(\mathrm{~F}\end{array}$ & & & & & & 0.01 & $\begin{array}{l}0.1 \\
\text { Fawours } L A 0\end{array}$ & $\begin{array}{l}10 \\
\text { Fauours } 00\end{array}$ & 100 \\
\hline
\end{tabular}

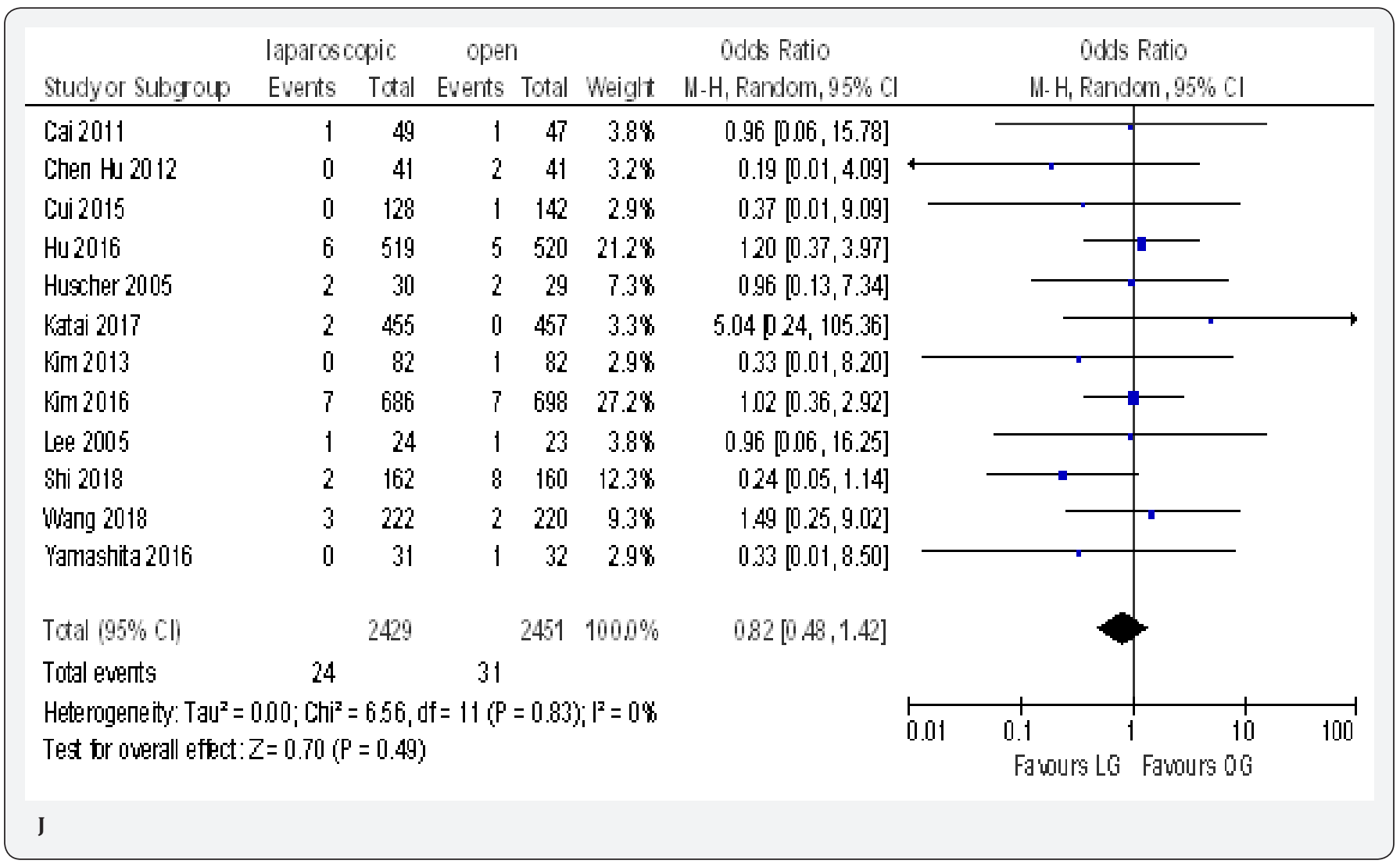




\section{Cancer Therapy \& Oncology International Journal}

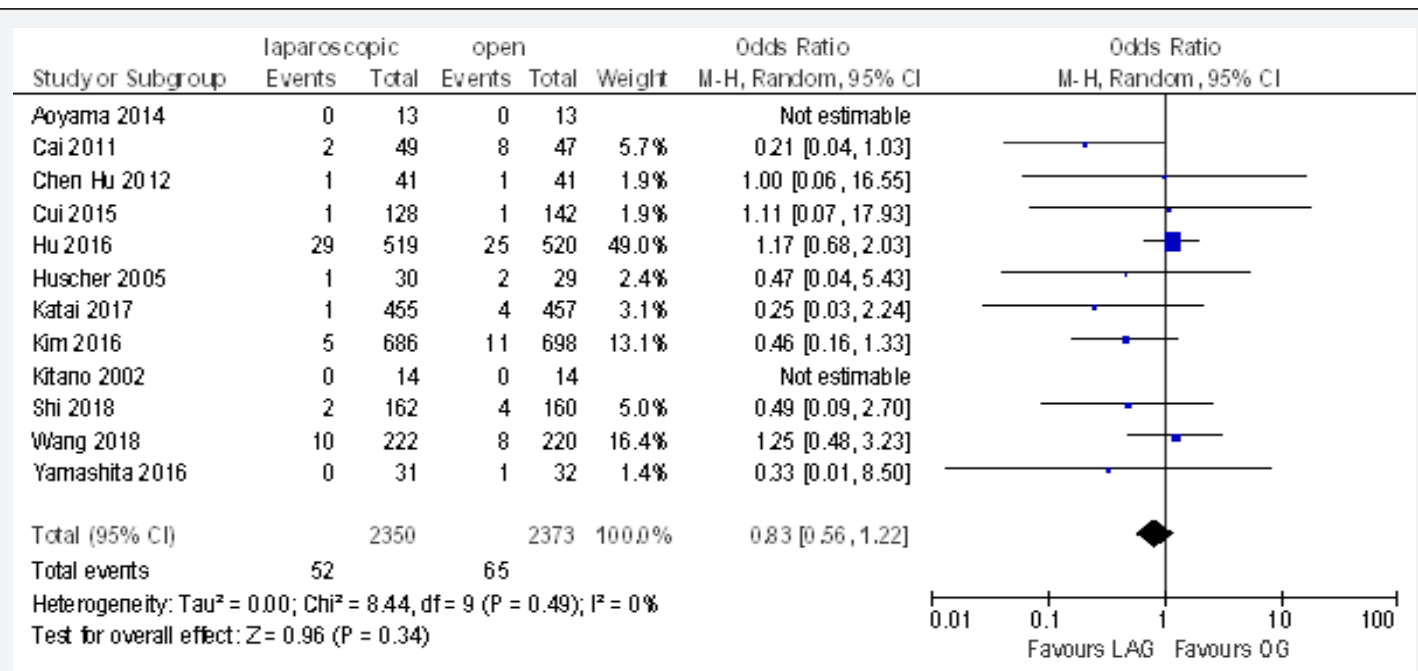

K

A: Abdominal Abscess; B: Anastomotic Leakage; C: Anastomotic Stenosis; D: Bleeding; E: Gastroparesis; F: Ileus; G: Intestinal Obstruction; H: Pancreatic Fistula; I: Pancreatitis; J: Wound Infection; K: Pneumonia

Figure 5: Meta-analyses of post- operative surgical and medical complications.

\section{Number of Harvested Lymph Nodes}

Data on number of harvested lymph nodes was available from all included trials [18-23,70-80]. These trials showed statistically significant reduction in lymph node harvesting for LAG group than for OG group (MD -1.55, 95\% CI - 2.43 to -0.67 , P $=0.0005)$ with moderate heterogeneity among trials $\left(\mathrm{I}^{2}=41 \%\right.$, $\mathrm{P}=0.04$ ) (Figure 6A).

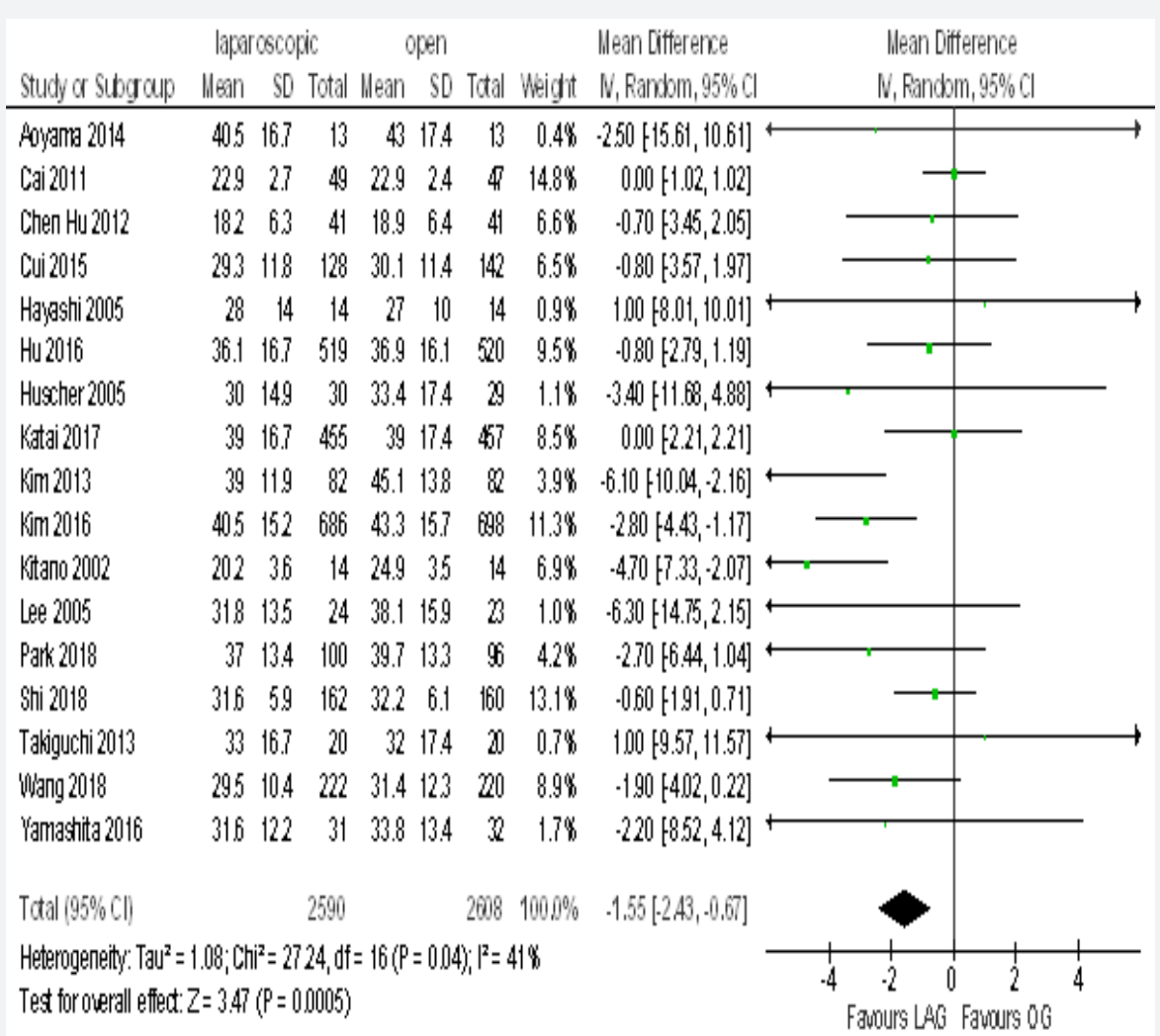

A 


\section{Cancer Therapy \& Oncology International Journal}

\section{Tumor Recurrence/Metastasis}

Data from six included trials totaling 389 participants were available to calculate odd ratio for tumor recurrence/metastasis
$[19,21-23,74,80]$. This pooled data showed no statistically significant difference between the two groups (OR 0.97, 95\% CI 0.36 to $2.56, \mathrm{P}=0.94)$ with no heterogeneity among trials $\left(\mathrm{I}^{2}=\right.$ $0 \%, \mathrm{P}=0.55$ ) (Figure 6B).

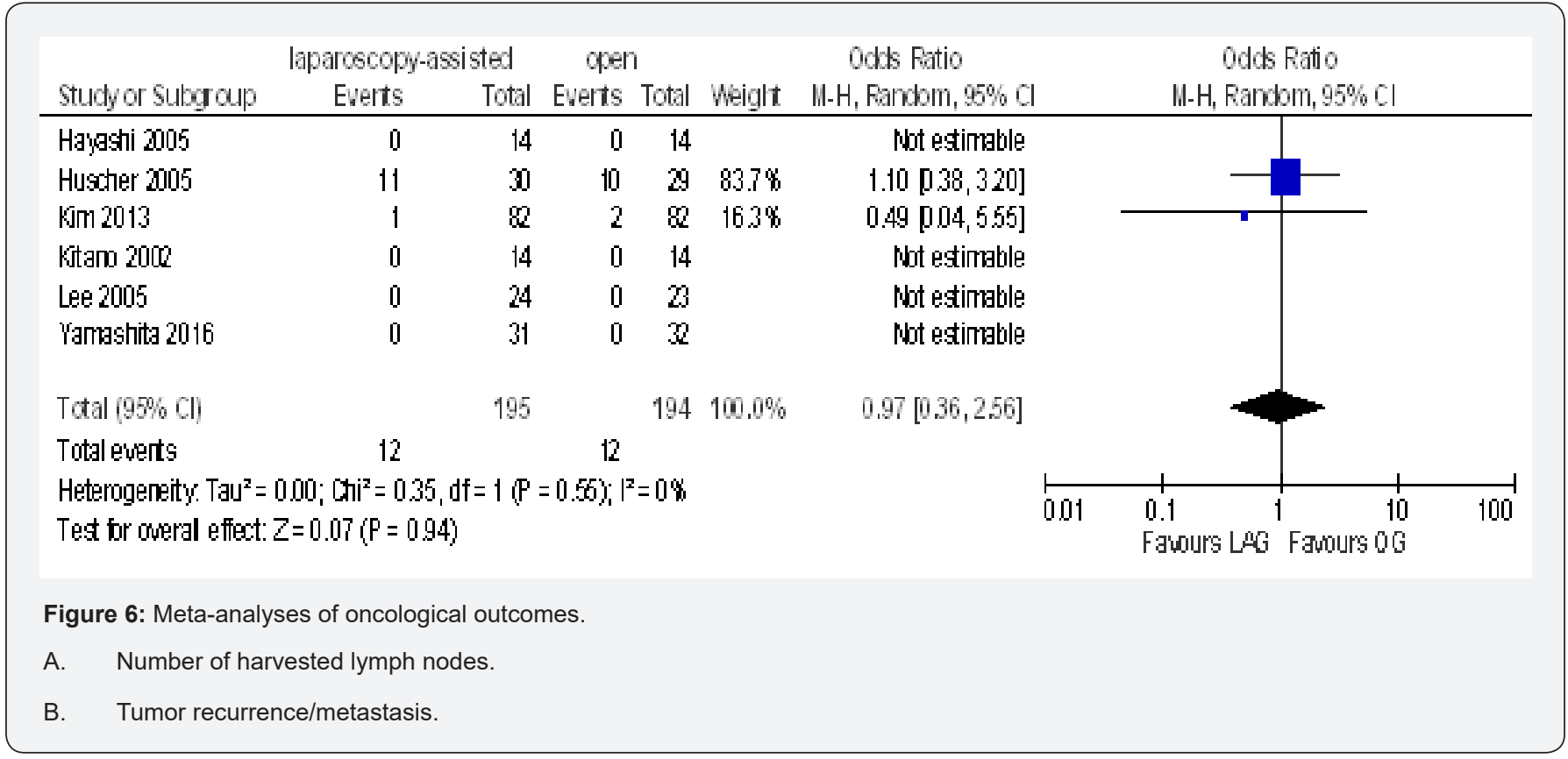

\section{Quality of Evidence}

GRADE working group evidence scores for the RCT outcomes are summarized in Table 2. The level of evidence was moderate for operative time [18-23,70-80], time to first oral intake [19$23,70-72,80]$. length of post-operative hospital stays [18-23,70$72,74-76,79,80]$, morbidity [18-23,70-80], mortality [18-22,70$80]$, number of harvested lymph nodes [18-23,70-80] and tumor recurrence/ metastasis. Low for intra-operative blood loss [18$23,70,71,73-80]$, number of thetransfused $[18,19,22,70,71,73,75$ 78] patients, frequency of analgesic consumption [21-23,71], and incidence of reoperation $[70,71,73,75,76]$. And very low in time to first ambulation $[20,23,70,71,76,77]$, and time to first flatus $[18-23,70,71,73,74,76,77,79]$.

\section{Discussion}

The number of gastric cancer patients undergoing laparoscopy-assisted gastrectomy has been increasing worldwide. However, it cannot be recommended for routine management of gastric cancer before its superiority over $O G$ is not guaranteed. The current meta-analysis examined whether LAG is an acceptable and safe alternative to $O G$ for gastric cancer patients from a clinical perspective. The strengths of this metaanalysis including adequate power with 5198 participants, in addition, we followed the PRISMA and GRADE evidence profile, all included studies were RCTs of good quality, operations were done by both eastern and western surgeons. the trials included patients of all ages and both genders furthermore, we included patients of gastric cancer from all pathological stages (early and advanced disease). So, the results are likely to be representative of the population of gastric cancer patients presented to the reporting centers.

The present study revealed that LAG offers less intraoperative blood loss, faster bowel recovery, shorter hospital stay, less frequency of analgesic consumption and less post-operative overall morbidity. Those benefits are attributed to the minimal invasiveness, which contributed to enhanced recovery after surgery. The less pain, better cosmetic effect and faster recovery could produce not only organic, but also psychological benefits to the patients. The less blood loss in LAG may be justified by the magnified view through the monitor, which allows careful dissection to prevent bleeding, thus preventing interference with surgical vision by blood accumulation [11].

No procedure associated differences were found in the incidence of reoperation and post-operative mortality, which supports the safety of LAG. However, western patients have been found to have higher post-operative mortality and morbidity rates compared with eastern patients [81]. This could be due to the fact that western patients have average higher BMI than eastern patients, which increase technical complexity of LAG with prolonged operative time, increased blood loss and risk of inadequate lymph node dissection. The second reason is that surgeons in eastern countries specially in Korea and Japan might be more experienced in the surgical management of gastric cancer than surgeons in the west. The third reason is that eastern patients presented with early stage tumors with a better 


\section{Cancer Therapy \& Oncology International Journal}

prognosis, thanks to the screening programs in those countries. Moreover, eastern patients are younger, healthier with lower rates of cardiovascular disease and lower risks of post-operative thromboembolic events than western patients.

This meta-analysis suggests that LAG has longer operative time as compared to OG. The finding was in line with many previous meta-analyses $[11,48,54]$. LAG with lymphadenectomy is a new, technically challenging and time-consuming procedure even for experienced surgeons who reached a learning curve plateau. A multivariate analysis revealed that operative time was affected by patients and tumor characteristics regardless of the surgeon's experience initially, followed by gradual decrease in the operative time once proficiency in the laparoscopic surgery has been achieved [82]. Therefore, in LAG, consideration to patients and tumor characteristics is much more important to solve this problem.

Oncological safety is very important in the surgical treatment of gastric cancer. Studies indicated that lymph node status is one of the most critical independent predictors of patient's gastrectomy for gastric malignancy $[83,84]$. Therefore, lymphadenectomy is important in the treatment of gastric cancer. The insufficient lymph node dissection for node-positive cases increases the potential risk of tumor recurrence [85]. In contrast to previous meta-analyses that shows reduction in the number of harvested lymph nodes in the laparoscopic group [34, 54], this meta-analysis clearly shows that there is no statistically significant difference in the number of lymph node harvested and the tumor recurrence/metastasis between the two groups, indicating oncological equivalence of both LAG and OG. Thus, LAG can be used as an alternative to OG for gastric cancer.

The current meta-analysis has few limitations. Firstly; sixteen out of the seventeenth included trials were conducted in east Asia [18-23,70-79], and only one trial conducted in Italy [80]. Thus , the included participants might not reflect the general patient's population ,furthermore the application of the results to western patients should be performed with caution. Secondly, none of the included trials reported quality of life scores or cost effectiveness, which are areas of concern. Finally, the long-term outcomes could not be assessed (Summary of findings).

\begin{tabular}{|c|c|c|c|c|c|c|}
\hline \multicolumn{7}{|c|}{ Summary of findings: } \\
\hline \multicolumn{7}{|c|}{ Laparoscopy-assisted gastrectomy compared to open gastrectomy for gastric cancer } \\
\hline \multicolumn{7}{|c|}{$\begin{array}{c}\text { Patient or population: gastric cancer } \\
\text { Setting: } \\
\text { Intervention: laparoscopy-assisted gastrectomy } \\
\text { Comparison: open gastrectomy }\end{array}$} \\
\hline \multirow[b]{2}{*}{ Outcomes } & \multicolumn{2}{|c|}{ Anticipated absolute effects ${ }^{*}(95 \% \mathrm{CI})$} & \multirow{2}{*}{$\begin{array}{l}\text { Relative effect } \\
(95 \% \mathrm{CI})\end{array}$} & \multirow{2}{*}{$\begin{array}{c}\text { № of participants } \\
\text { (studies) }\end{array}$} & \multirow{2}{*}{$\begin{array}{l}\text { Certainty of the } \\
\text { evidence } \\
\text { (GRADE) }\end{array}$} & \multirow[b]{2}{*}{ Comments } \\
\hline & $\begin{array}{l}\text { Risk with open } \\
\text { gastrectomy }\end{array}$ & $\begin{array}{l}\text { Risk with laparoscopy-as- } \\
\text { sisted gastrectomy }\end{array}$ & & & & \\
\hline Operative time & & $\begin{array}{c}\text { MD } 67.9 \text { higher } \\
\text { (54.51 higher to } 81.3 \\
\text { higher) }\end{array}$ & - & $\begin{array}{c}5198 \\
(17 \text { RCTs) }\end{array}$ & $\begin{array}{c}\oplus \oplus \oplus \bigcirc \\
\text { MODERATE }^{\text {a }}\end{array}$ & \\
\hline $\begin{array}{l}\text { intra-operative } \\
\text { blood loss }\end{array}$ & & $\begin{array}{c}\text { MD } 73.55 \text { lower } \\
\text { (98.17 lower to } 48.93 \\
\text { lower) }\end{array}$ & - & $\begin{array}{c}4902 \\
(16 \text { RCTs) }\end{array}$ & $\begin{array}{l}\oplus \oplus \bigcirc \bigcirc \\
\mathrm{LOW}\end{array}$ & \\
\hline $\begin{array}{l}\text { Transfused } \\
\text { patients }\end{array}$ & 35 per 1,000 & $\begin{array}{l}27 \text { per } 1,000 \\
(19 \text { to } 38)\end{array}$ & $\begin{array}{c}\text { OR } 0.76 \\
(0.53 \text { to } 1.09)\end{array}$ & $\begin{array}{c}4627 \\
\text { (10 RCTs) }\end{array}$ & $\underset{\mathrm{LOW}}{\oplus} \mathrm{a}^{\mathrm{a}}$ & \\
\hline $\begin{array}{l}\text { post-operative } \\
\text { analgesic con- } \\
\text { sumpsion }\end{array}$ & & $\begin{array}{c}\text { MD } 1.33 \text { lower } \\
\text { (1.62 lower to } 1.04 \text { lower) }\end{array}$ & - & $\begin{array}{c}425 \\
\text { (4 RCTs) }\end{array}$ & $\underset{\mathrm{LOW}}{\oplus \oplus \bigcirc \bigcirc}$ & \\
\hline
\end{tabular}

Outcomes

\begin{tabular}{|c|c|c|c|c|c|}
\hline Time to first ambulation & & MD 0.49 lower ( 0.89 lower to 0.09 lower) & - & $\begin{array}{c}2197 \\
\text { (6 RCTs) }\end{array}$ & $\begin{array}{l}\oplus \bigcirc \bigcirc \bigcirc \\
\text { VERY LOW }\end{array}$ \\
\hline Time to first flatus & & MD 1.14 lower (1.68 lower to 0.6 lower) & - & $\begin{array}{c}3533 \\
\text { (13 RCTs) }\end{array}$ & $\begin{array}{l}\oplus \bigcirc \bigcirc \bigcirc \\
\text { VERY LOW }\end{array}$ \\
\hline Time to first oral intake & & MD 0.59 lower (1.03 lower to 0.14 lower) & - & $\begin{array}{c}1382 \\
\text { (9 RCTs) }\end{array}$ & $\begin{array}{c}\oplus \oplus \oplus \bigcirc \\
\text { MODERATE }^{\mathrm{a}}\end{array}$ \\
\hline $\begin{array}{c}\text { Length of post-operative } \\
\text { hospital stay }\end{array}$ & & MD 1.15 lower (1.09 lower to 0.4 lower) & - & $\begin{array}{c}3990 \\
\text { (14 RCTs) }\end{array}$ & $\begin{array}{c}\oplus \oplus \oplus \bigcirc \\
\text { MODERATE }^{\mathrm{a}}\end{array}$ \\
\hline $\begin{array}{l}\text { post-operative overall } \\
\text { morbidity }\end{array}$ & $\begin{array}{l}151 \text { per } \\
1,000\end{array}$ & 124 per 1,000 (103 to 149 ) & $\begin{array}{c}\text { OR } 0.80 \\
(0.65 \text { to } 0.99)\end{array}$ & $\begin{array}{c}5198 \\
\text { (17 RCTs) }\end{array}$ & $\begin{array}{c}\oplus \oplus \oplus \bigcirc \\
\text { MODERATE }^{\text {a }}\end{array}$ \\
\hline Reoperation & $\begin{array}{l}15 \text { per } \\
1,000\end{array}$ & 13 per 1,000 ( 7 to 22$)$ & $\begin{array}{c}\text { OR } 0.87 \\
\text { (0.51 to } 1.49)\end{array}$ & $\begin{array}{c}4099 \\
\text { (5 RCTs) }\end{array}$ & $\begin{array}{c}\oplus \oplus \bigcirc \bigcirc \\
\mathrm{LOW}^{\mathrm{a}}\end{array}$ \\
\hline Mortality & $\begin{array}{l}2 \text { per } \\
1,000\end{array}$ & $\begin{array}{l}1 \text { per } 1,000 \\
(0 \text { to } 7)\end{array}$ & $\begin{array}{c}\text { OR } 0.84 \\
(0.16 \text { to } 4.36)\end{array}$ & $\begin{array}{c}3786 \\
\text { (15 RCTs) }\end{array}$ & $\begin{array}{c}\oplus \oplus \oplus \bigcirc \\
\text { MODERATE }^{\mathrm{a}}\end{array}$ \\
\hline
\end{tabular}




\section{Cancer Therapy \& Oncology International Journal}

\begin{tabular}{|c|c|c|c|c|c|c|}
\hline $\begin{array}{c}\text { number of harvested lymph } \\
\text { nodes }\end{array}$ & & $\begin{array}{c}\text { MD } 1.55 \text { lower } \\
\text { (2.43 lower to } 0.67 \text { lower) }\end{array}$ & - & $\begin{array}{c}5198 \\
\text { (17 RCTs) } \\
\end{array}$ & $\begin{array}{c}\oplus \oplus \oplus \bigcirc \\
\text { MODERATE }^{a}\end{array}$ & \\
\hline $\begin{array}{c}\text { Tumour recurrence and } \\
\text { metastasis }\end{array}$ & 62 per 1,000 & $\begin{array}{l}60 \text { per } 1,000 \\
(23 \text { to } 144)\end{array}$ & $\begin{array}{c}\text { OR } 0.97 \\
(0.36 \text { to } 2.56)\end{array}$ & $\begin{array}{c}389 \\
\text { (6 RCTs) }\end{array}$ & $\begin{array}{c}\oplus \oplus \oplus \bigcirc \\
\text { MODERATE }^{a}\end{array}$ & \\
\hline \multicolumn{7}{|c|}{$\begin{array}{c}\text { *The risk in the intervention group (and its 95\% confidence interval) is based on the assumed risk in the comparison group and the relative } \\
\text { effect of the intervention (and its } 95 \% \mathrm{CI} \text { ). }\end{array}$} \\
\hline \multicolumn{7}{|c|}{$\begin{array}{l}\text { GRADE Working Group grades of evidence } \\
\text { High certainty: We are very confident that the true effect lies close to that of the estimate of the effect } \\
\text { Moderate certainty: We are moderately confident in the effect estimate: The true effect is likely to be close to the estimate of the effect, but there is } \\
\text { a possibility that it is substantially different } \\
\text { Low certainty: Our confidence in the effect estimate is limited: The true effect may be substantially different from the estimate of the effect } \\
\text { Very low certainty: We have very little confidence in the effect estimate: The true effect is likely to be substantially different from the estimate of } \\
\text { effect }\end{array}$} \\
\hline
\end{tabular}

\section{Explanations}

a. Because of the nature of the procedure, its very difficult to perform blinging.

b. Unexplained statistically significant heterogeneity among included trials.

\section{Conclusion}

Despite the fact that LAG is a technically demanding and timeconsuming procedure, the results of our meta-analysis suggests that LAG can be used as a safe and acceptable alternative to OG for gastric cancer with similar mortality rates, comparable oncological results, less intra-operative blood loss, decreased post-operative morbidity, faster recovery and earlier hospital discharge. Further large well-designed multi-center RCTs are required to evaluate its long-term oncological outcomes.

\section{Acknowledgement}

The author gratefully acknowledged doctor Doha Ibrahim, Doctor Malaz Ahmed, Ayat Ali for their continuous support.

\section{Funding}

No source of funding

\section{Conflict of Interest}

None declare.

\section{References}

1. RL Siegel, KD Miller, A Jemal (2018) Cancer statistics, 2018. CA Cancer J Clin 68(1): 7-30.

2. J Ferlay, I Soerjomataram, R Dikshit, S Eser, C Mathers, et al. (2012) Cancer incidence and mortality worldwide: sources, methods and major patterns in GLOBOCAN 2012. Int J Cancer 136(5): E359-E386.

3. World Cancer Research Fund/American Institute for Cancer Research Diet, Nutrition, Physical Activity and Cancer: A Global Perspective. Continuous Update Project Expert Report 2018.

4. Guggenheim DE, Shah MA (2013) Gastric cancer epidemiology and risk factors. J Surg Oncol 107(3): 230-236.

5. Siegel R, Ma J, Zou Z, Jemal A (2014) Cancer statistics, 2014. CA Cancer J Clin 64(1): 9-29.

6. Edge SB, Byrd DR, Compton CC, Fritz AG, Greene FL, et al. (2010) AJCC Cancer Staging Manual. $7^{\text {th }}(E d n)$, Springer, New York, USA.

7. Washington $\mathrm{K}(2010) 7^{\text {th }}$ edition of the AJCC cancer staging manual: stomach. Annals of Surgical Oncology 17(12): 3077-3079.
8. Japanese Gastric Cancer Association (2011) Japanese gastric cancer treatment guidelines: $3^{\text {rd }}$ English Edition. Gastric Cancer 14(2): 113123.

9. Kitano S, Iso Y, Moriyama M, Sugimachi K (1994) Laparoscopy assisted Billroth I gastrectomy. Surg. Laparosc Endosc 4(2): 146-148.

10. Goh PM, Alponat A, Mak K, Kum CK (1997) Early international results of laparoscopic gastrectomies. Surg Endosc 11(6): 650-652.

11. Zhang CD, Yamashita H, Zhang S, Seto Y (2018) Reevaluation of laparoscopic versus open distal gastrectomy for early gastric cancer in Asia: a meta-analysis of randomized controlled trials. Int J Surg 56: 31-43.

12.J Ferlay, I Soerjomataram, R Dikshit, S Eser, C Mathers, et al. (2015) Cancer incidence and mortality worldwide: sources, methods and major patterns in GLOBOCAN 2012. Int J Cancer 136(5): E359-E386.

13. L Zong, M Abe, Y Seto, J Ji (2016) The challenge of screening for early gastric cancer in China. Lancet 388(10060): 2606.

14. Sumiyama K (2017) Past and current trends in endoscopic diagnosis for early stage gastric cancer in Japan, Gastric. Cancer 20(Suppl 1): 20-27.

15. C Hamashima (2018) Cancer screening guidelines and policy making: 15 years of experience in cancer screening guideline development in Japan. J Clin Oncol 48(3): 278-286.

16. Best LM, Mughal M, Gurusamy KS (2014) Laparoscopic versus open gastrectomy for gastric cancer. Cochrane Database of Systematic Reviews 3: CD011389.

17. Azagra JS, Goergen M, De Simone P, Ibañez-Aguirre J (1999) Minimally invasive surgery for gastric cancer. Surg Endosc 13(4): 351-357.

18.S Takiguchi, Y Fujiwara, M Yamasaki, H Miyata, K Nakajima, et al. (2013) Laparoscopy-assisted distal gastrectomy versus open distal gastrectomy. A prospective randomized single-blind study, World J Surg 37(10): 2379-2386.

19. YW Kim, HM Yoon, YH Yun, BH Nam, BW Eom, et al. (2013) Long-term outcomes of laparoscopy-assisted distal gastrectomy for early gastric cancer: result of a randomized controlled trial (COACT 0301), Surg Endosc 27(11): 4267-4276.

20. Cai J, Wei D, Gao CF, Zhang CS, Zhang H, et al. (2011) A prospective randomized study comparing open versus laparoscopy assisted D2 radical gastrectomy in advanced gastric cancer. Dig Surg 28(5-6): 331-337. 


\section{Cancer Therapy \& Oncology International Journal}

21. JH Lee, HS Han, JH Lee (2005) A prospective randomized study comparing open vs laparoscopy-assisted distal gastrectomy in early gastric cancer: early results. Surg Endosc 19(2): 168-173.

22. H Hayashi, T Ochiai, H Shimada, Y Gunji (2005) Prospective randomized study of open versus laparoscopy-assisted distal gastrectomy with extraperigastric lymph node dissection for early gastric cancer. Surg Endosc 19(9): 1172-1176.

23. S Kitano, N Shiraishi, K Fujii, K Yasuda, M Inomata, et al. (2002) A randomized controlled trial comparing open vs laparoscopy-assisted distal gastrectomy for the treatment of early gastric cancer: an interim report. Surgery 131(1 Suppl): S306-S311.

24. Fujii K, Sonoda K, Izumi K, Shiraishi N, Adachi Y, et al. (2003) T lymphocyte subsets and Th1/Th2 balance after laparoscopy-assisted distal gastrectomy. Surg Endosc 17(9): 1440-1444.

25. K Nakamura, H Katai, J Mizusawa, T Yoshikawa, M Ando, et al (2013) A phase III study of laparoscopy-assisted versus open distal gastrectomy with nodal dissection for clinical stage IA/IB gastric Cancer (JCOG0912). Jpn J Clin Oncol 43(3): 324-327.

26. K Misawa, M Fujiwara, M Ando, S Ito, Y Mochizuki, et al. (2015) Longterm quality of life after laparoscopic distal gastrectomy for early gastric cancer: results of a prospective multi-institutional comparative trial. Gastric Cancer 18(2): 417-425.

27. JH Lee, BH Nam, KW Ryu, SY Ryu, YK Park, et al. (2015) Comparison of outcomes after laparoscopy-assisted and open total gastrectomy for early gastric cancer. Br J Surg 102(2015): 1500-1505.

28. T Yoshikawa, H Cho, Y Rino, Y Yamamoto, M Kimura, et al. (2013) A prospective feasibility and safety study of laparoscopy-assisted distal gastrectomy for clinical stage I gastric cancer initiated by surgeons with much experience of open gastrectomy and laparoscopic surgery. Gastric Cancer 16(2): 126-132.

29. H Katai, M Sasako, H Fukuda, K Nakamura, N Hiki (2010) JCOG Gastric Cancer Surgical Study

Group, Safety and feasibility of laparoscopy-assisted distal gastrectomy with suprapancreatic nodal dissection for clinical stage I gastric cancer: a multicenter phase II trial (JCOG 0703). Gastric Cancer 13 238-244.

30. Y Kurokawa, H Katai, H Fukuda, M Sasako (2008) Gastric Cancer Surgical Study Group of the Japan Clinical Oncology Group, Phase II study of laparoscopy-assisted distal gastrectomy with nodal dissection for clinical stage I gastric cancer: Japan Clinical Oncology Group Study JCOG0703. Jpn J Clin Oncol 38(7): 501-503.

31. JY An, GU Heo, JH Cheong, WJ Hyung, SH Choi, et al. (2010) Assessment of open versus laparoscopy-assisted gastrectomy in lymph nodepositive early gastric cancer: a retrospective cohort analysis. J Surg Oncol 102(1): 77-81.

32. Y Wang, S Wang, ZQ Huang, WP Chou (2014) Meta-analysis of laparoscopy assisted distal gastrectomy and conventional open distal gastrectomy for EGC. Surgeon 12(1): 53-58.

33. Y Deng, Y Zhang, TK Guo TK (2015) Laparoscopy-assisted versus open distal gastrectomy for early gastric cancer: A meta-analysis based on seven randomized controlled trials. Surg Oncol 24(2): 71-77.

34. W Lu, J Gao, J Yang, Y Zhang, W Lv, et al. (2016) Long-term clinical outcomes of laparoscopy-assisted distal gastrectomy versus open distal gastrectomy for early gastric cancer: A comprehensive systematic review and meta-analysis of randomized control trials. Medicine (Baltimore) 95(27): e3986.

35. JPT Higgins, S Green (2011) Cochrane Handbook for Systematic Reviews of Interventions Version 5.1.0. The Cochrane Collaboration.

36. Moher D, Liberati A, Tetzlaff J, Altman DG (2009) Preferred reporting items for systematic reviews and meta-analyses: the PRISMA statement. PLoS Med 6: e1000097.
37. Higgins JPT, Green S (2011) Cochrane Handbook for Systematic Reviews of Interventions (version 5.1.0.). Hoboken: John Wiley \& Sons Inc, New Jersey, USA.

38. Inaba T, Okinaga K, Fukushima R, Iinuma H, Ogihara T, et al. (2004) Prospective randomized study of two laparotomy incisions for gastrectomy: midline incision versus transverse incision. Gastric Cancer 7(3): 167-171.

39. Stuart RC (1997) 4 - Radical gastrectomy - how do I do it?. European Journal of Cancer 33(Suppl 8): S5.

40. Lee HJ, Yang HK (2013) Laparoscopic gastrectomy for gastric cancer Digestive Surgery 30(2): 132-141.

41. Han SU (2014) Laparoscopy-assisted endoscopic full-thickness resection with basin lymphadenectomy based on sentinel lymph nodes for early gastric cancer. J Am Coll Surg 219(3): e29-37.

42. Kawamura H, Homma S, Yokota R, Yokota K, Watarai H, et al. (2008) Inspection of safety and accuracy of D2 lymph node dissection in laparoscopy-assisted distal gastrectomy. World J Surg 32(11): 23662370.

43. Lee SJ, Hyung WJ, Koo BN, Lee JY, Jun NH, et al. (2008) Laparoscopyassisted subtotal gastrectomy under thoracic epidural-general anesthesia leading to the effects on postoperative micturition. Surgical Endoscopy 22(3): 724-730.

44. Lee JH, Yom CK, Han HS (2009) Comparison of longterm outcomes of laparoscopy-assisted and open distal gastrectomy for early gastric cancer. Surgical Endoscopy 23(8): 1759-1763.

45. Li HT, Han XP, Su L, Zhu WK, Xu W, et al. (2014) Short-term efficacy of laparoscopy-assisted vs open radical gastrectomy in gastric cancer. World J Gastrointest Surg 6(4): 59-64.

46. Lin W, Li Z, Xu Y, Xie X, Huang Z, et al. (2014) Comparative study of laparoscopic gastrectomy D2 radical surgery and open gastrectomy for upper stomach cancer. Cancer Research and Clinic 26(5): 332-335.

47. DU XH, Li R, Chen L, Shen D, Li SY, et al. (2009) Laparoscopyassisted D2 radical distal gastrectomy for advanced gastric cancer: initial experience. Chin Med J (Engl) 122(12): 1404-1407.

48. Jiang L, Yang KH, Guan QL, Cao N, Chen Y, et al. (2013) Laparoscopyassisted gastrectomy versus open gastrectomy for resectable gastric cancer: an update meta-analysis based on randomized controlled trials. Surg Endosc 27(7): 2466-2480.

49. Cheng QY, Pang TCY, Hollands MJ, Richardson AJ, Pleass H, et al. (2014) Systematic review and meta-analysis of laparoscopic versus open distal gastrectomy. J Gastrointest Surg 18: 1087-1099.

50. Aurello P, Sagnotta A, Terrenato I, Berardi G, Nigri G, et al. (2016) Oncologic value of laparoscopy-assisted distal gastrectomy for advanced gastric cancer: a systematic review and meta-analysis. J Minim Access Surg 12(3): 199-208.

51. Inokuchi M, Otsuki S, Ogawa N, Tanioka T, Okuno K, et al. (2016) Postoperative complications of laparoscopic total gastrectomy versus open total gastrectomy for gastric cancer in a meta-analysis of highquality case-controlled studies. Gastroenterol Res Pract 27(5): 15091520.

52. XZ Chen, JK Hu, K Yang, L Wang, QC Lu (2009) Short-term evaluation of laparoscopy-assisted distal gastrectomy for predictive early gastric cancer: a meta-analysis of randomized controlled trials. Surg Laparosc Endosc Percutan Tech 19(4): 277-284.

53. H Ohtani, Y Tamamori, K Noguchi, T Azuma, S Fujimoto, et al. (2010) A meta-analysis of randomized controlled trials that compared laparoscopy-assisted and open distal gastrectomy for early gastric cancer. J Gastrointest Surg 14: 958-964.

54. Y Liang, G Li, P Chen, J Yu, C Zhang (2011) Laparoscopic versus open gastrectomy for early distal gastric cancer: a meta-analysis. ANZ J Surg 81(10): 673-680. 


\section{Cancer Therapy \& Oncology International Journal}

55. YK Zeng, ZL Yang, JS Peng, HS Lin, L Cai (2012) Laparoscopy-assisted versus open distal gastrectomy for early gastric cancer: evidence from randomized and nonrandomized clinical trials. Ann Surg 256(1): 3952.

56. Scatizzi M, Kröning KC, Lenzi E, Moraldi L, Cantafio S, et al. (2011) Laparoscopic versus open distal gastrectomy for locally advanced gastric cancer: a case-control study. Updates Surg 63(1): 17-23.

57. Shinohara T, Satoh S, Kanaya S, Ishida Y, Taniguchi K, et al. (2013) Laparoscopic versus open D2 gastrectomy for advanced gastric cancer: a retrospective cohort study. Surg Endosc 27(1): 286-294.

58. Lee J, Kim YM, Woo Y, Obama K, Noh SH, et al. (2015) Robotic distal subtotal gastrectomy with D2 lymphadenectomy for gastric cancer patients with high body mass index: comparison with conventiona laparoscopic distal subtotal gastrectomy with D2 lymphadenectomy. Surg Endosc 29(11): 3251-3260.

59. Kim HI, Han SU, Yang HK, Kim YW, Lee HJ, et al. (2016) Multicenter prospective comparative study of robotic versus laparoscopic Gastrectomy for gastric Adenocarcinoma. Ann Surg 263(1): 103-109.

60. Okumura N, Son T, Kim YM, Kim HI, An JY, et al. (2016) Robotic gastrectomy for elderly gastric cancer patients: comparisons with robotic gastrectomy in younger patients and laparoscopic gastrectomy in the elderly. Gastric Cancer 19(4): 1125-1134.

61. Luo GD, Cao YK, Gong JQ, Wang XH, Wang B, et al. (2017) Hand-assisted laparoscopic versus open surgery radical gastrectomy for advanced distal gastric cancer: a prospective randomized study. Int J Clin Exp Med 10: 5001-5010.

62. Inaki N, Etoh T, Ohyama T, Uchiyama K, Katada N, et al. (2015) A multiinstitutional, prospective, phase II feasibility study of laparoscopyassisted distal gastrectomy with D2 lymph node dissection for locally advanced gastric cancer (JLSSG0901). World J Surg 39(11): 27342741.

63. Kim HI, Hur H, Kim YN, Lee HJ, Kim MC, et al. (2014) Standardization of D2 lymphadenectomy and surgical quality control (KLASS-02-QC): a prospective, observational, multicenter study [NCT01283893]. BMC Cancer 14: 209

64. S Sakuramoto, K Yamashita, S Kikuchi, N Futawatari, N Katada, et al. Laparoscopy versus open distal gastrectomy by expert surgeons for early gastric cancer in Japanese patients: short-term clinical outcomes of a randomized clinical trial. Surg Endosc 27(5): 1695-1705.

65. YW Kim, YH Baik, YH Yun, BH Nam, DH Kim et al. (2008) Improved quality of life outcomes after laparoscopy-assisted distal gastrectomy for early gastric cancer: results of a prospective randomized clinical trial. Ann Surg 248(5): 721-727.

66. HH Kim, WJ Hyung, GS Cho, MC Kim, SU Han et al. (2010) Morbidity and mortality of laparoscopic gastrectomy versus open gastrectomy for gastric cancer: an interim report-a phase III multicenter, prospective, randomized Trial (KLASS Trial). Ann Surg 251(3): 417-420.

67. Kim YW, Park YK, Yoon HM, Nam BH, Ryu KW, et al. (2013) Result of clinical study on feasibility of laparoscopy assisted D2 distal gastrectomy to treat advanced gastric cancer (COACT_1001). J Clin Oncol 31(15): 4105.

68. Nam BH, Kim YW, Reim D, Eom BW, Yu WS, et al. (2013) Laparoscopy assisted versus open distal gastrectomy with D2 lymph node dissection for advanced gastric cancer: design and rationale of a phase II randomized controlled multicenter trial (COACT 1001). J Gastric Cancer 13(3): 164-171.

69. Hu YF, Huang CM, Sun YH, Su XQ, Li ZY, et al. (2015) Laparoscopic D2 distal gastrectomy versus conventional open surgery for advanced gastric cancer: the safety analysis from a multicenter prospective randomized controlled trial in China (CLASS-01 Trial). J Clin Oncol 33(3): 1350-1357.
70. Wang Z, Xing J, Cai J, Zhang Z, Li F, et al. (2018) Short-term surgical outcomes of laparoscopy-assisted versus open D2 distal gastrectomy for locally advanced gastric cancer in North China: a multicenter randomized controlled trial. Surg Endosc 33(1): 33-45.

71. Shi Y, Xu X, Zhao Y, Qian F, Tang B, et al. (2018) Short-term surgical outcomes of a randomized controlled trial comparing laparoscopic versus open gastrectomy with D2 lymph node dissection for advanced gastric cancer. Surg Endosc 32(5): 2427-2433.

72. Park YK, Yoon HM, Kim YW, Park JY, Ryu KW, et al. (2018) Laparoscopyassisted versus open D2 distal gastrectomy for advanced gastric cancer: results from a randomized phase II multicenter clinical trial (COACT 1001). Ann Surg 267(4): 638-645.

73. H Katai, J Mizusawa, H Katayama, M Takagi, T Yoshikawa, et al. (2017) Short-term surgical outcomes from a phase III study of laparoscopyassisted versus open distal gastrectomy with nodal dissection for clinical stage IA/IB gastriccancer: Japan Clinical Oncology Group Study JCOG0912. Gastric Cancer 20(4): 699-708.

74. K Yamashita, S Sakuramoto, S Kikuchi, N Futawatari, N Katada, et al (2016) Laparoscopic versus open distal gastrectomy for early gastric cancer in Japan: long-term clinical outcomes of a randomized clinical trial Surg Today 46(6): 741-749.

75. W Kim, HH Kim, SU Han, MC Kim, WJ Hyung (2016) Korean Laparoendoscopic Gastrointestinal Surgery Study (KLASS) Group, Decreased Morbidity of Laparoscopic Distal Gastrectomy Compared with Open Distal Gastrectomy for Stage I Gastric Cancer: Short-term Outcomes from a Multicenter Randomized Controlled Trial (KLASS-01). Ann Surg 263: 28-35.

76. Hu Y, Huang C, Sun Y, Su X, Cao H, et al. (2016) Morbidity and mortality of laparoscopic versus open D2 distal gastrectomy for advanced gastric cancer: a randomized controlled trial. J Clin Oncol 34(12): 1350-1357.

77. Cui M, Li Z, Xing J, Yao Z, Liu M, et al. (2015) A prospective randomized clinical trial comparing D2 dissection in laparoscopic and open gastrectomy for gastric cancer. Med Oncol 32(10): 241

78. Aoyama T, Yoshikawa T, Hayashi T, Hasegawa S, Tsuchida K, et al. (2014) Randomized comparison of surgical stress and the nutritional status between laparoscopy assisted and open distal gastrectomy for gastric cancer. Ann Surg Oncol 21(6): 1983-1990.

79. Chen Hu J, Xin Jiang L, Cai L, Tao Zheng H, et al. (2012) Preliminary experience of fast-track surgery combined with laparoscopy-assisted radical distal gastrectomy for gastric cancer. J Gastrointest Surg 16(10): 1830-1839.

80. Huscher CG, Mingoli A, Sgarzini G, Sansonetti A, Di Paola M, et al (2005) Laparoscopic versus open subtotal gastrectomy for distal gastric cancer: Five-year results of a randomized prospective trial. Ann Surg 241(2): 232-237.

81. Strong VE, Song KY, Park CH, Jacks LM, Gonen M, et al. (2010) Comparison of gastric cancer survival following R0 resection in the United States and Korea using an internationally validated nomogram. Ann Surg 251(4): 640-646.

82. Hyung WJ, Song C, Cheong JH, Choi SH, Noh SH (2007) Factors influencing operation time of laparoscopy-assisted subtotal gastrectomy: analysis of consecutive initial 100 cases. Eur J Surg Oncol 33(3): 314-319.

83. Seto Y, Nagawa H, Muto T (1997) Impact of lymph node metastasis on survival with early gastric cancer. World J Surg 21(2): 186-189.

84. Siewert JR, Bottcher K, Stein HJ, Roder JD (1998) Relevant prognostic factors in gastric cancer: ten-year results of the German gastric cancer study. Ann Surg 228(4): 449-461.

85. Roviello F, Rossi S, Marrelli D, Pedrazzani C, Corso G, et al. (2006) Number of lymph node metastases and its prognostic significance in early gastric cancer: a multicenter Italian study. J Surg Oncol 94(4): $275-280$. 


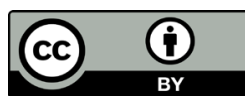

This work is licensed under Creative Commons Attribution 4.0 License DOI: 10.19080/CTOIJ.2019.15.555904

\section{Your next submission with Juniper Publishers} will reach you the below assets

- Quality Editorial service

- Swift Peer Review

- Reprints availability

- E-prints Service

- Manuscript Podcast for convenient understanding

- Global attainment for your research

- Manuscript accessibility in different formats ( Pdf, E-pub, Full Text, Audio)

- Unceasing customer service

Track the below URL for one-step submission https://juniperpublishers.com/online-submission.php 
